\title{
CONDUCTAS TÍPICAS EN EL DELITO DE ATENTADO CONTRA EL PERSONAL DE SEGURIDAD PRIVADA: ALGUNAS PROPUESTAS PARA SU INTERPRETACIÓN
}

\author{
Noel Villalba López \\ Universidad Carlos III de Madrid
}

SumARIO: 1. Planteamiento de la cuestión. 2. La Ley 5/2014, de 4 de abril, de Seguridad Privada. 3. Bien jurídico protegido en el art. 554.3.b) del Código Penal. 3.1. Seguridad personal, pública y ciudadana en la Constitución. 3.2 El orden público en la Constitución. 3.3 Bien jurídico protegido en el Capítulo II, Título XXII del Código Penal. 3.4 Especialidad del artículo 554.3.b) del Código Penal. 4. Tres ojeadas al artículo 554.3.b) del Código Penal. 4.1 Primera ojeada. El artículo 554.3.b) en solitario. 4.2 Segunda ojeada. El artículo 554.3.b) dentro del artículo 554. 4.3 Tercera ojeada. Los artículos 554.3.b) y 550.1. 5. Conductas típicas del artículo 554.3.b) del Código Penal. 5.1 Conductas típicas del art. 550 en el CP de 1995. 5.2 El acometimiento en el artículo 554.3.b) del Código Penal. 5.2.1 ¿Acometimiento sin agresión? 5.2.2 Acometimiento y casos frontera con la intimidación grave. 5.2.3 La omisión de la resistencia en el artículo 554.3 del Código Penal. 6. Conclusiones. 7. Referencias bibliográficas.

Resumen: Este artículo expone las dificultades interpretativas que presentan las conductas típicas del delito de atentado contra el personal de seguridad privada. Se propone una determinada interpretación de los verbos típicos a partir de un triple análisis del delito en relación con su bien jurídico protegido, el tenor literal de su precepto regulador y su relación con el delito de atentado «clásico».

Palabras clave: Atentado, seguridad privada, art. 554.3.b), conducta típica.

Abstract: This paper accounts for the interpretative problems arising from the conducts defined as criminal in the crime of attack against private security staff members. A three-pronged study of the legal interest protected therewith, the precept's wording and its relation with the classic crime of attack against authorities, agents thereof or public servants provides for an interpretative proposal of such conducts.

Key words: Attack, private security, art. 554.3. b), conducts defined as criminal. 


\section{Planteamiento de la cuestión}

Entre otras célebres novedades, la reforma del Código penal de 2015 nos dejó un reguero de cambios en la configuración de los delitos de atentado, resistencia y desobediencia (capítulo II, Título XXII del Código). Solo en relación con el atentado, se reformó el vetusto - de 1870esquema cuatrimodal de modalidades comisivas «clásicas» (art. 550.1 $\mathrm{CP}$ ), se introdujeron varias nuevas agravantes al mismo (art. $551 \mathrm{CP}$ ) y se habilitó un art. $554 \mathrm{CP}$ cajón de sastre donde pasaron a convivir todos los supuestos de atentado «atípicos» en función del sujeto pasivo, tanto los dos previos a la LO $1 / 2015^{1}$ —notablemente reformados-como dos de nuevo cuño ${ }^{2}$. A todo esto se aludirá a lo largo de las siguientes líneas.

Pero conviene antes perfilar nuestro concreto objeto de estudio. Entre los nuevos supuestos «atípicos» del art. $554 \mathrm{CP}$ existe uno que, aunque de momento no suscite demasiadas polémicas doctrinales, es a mi juicio lo más importante de este grupo de reformas pues su inclusión supone un paso decisivo en el sibilino y ya avanzado desmantelamiento del modelo tradicional de seguridad ciudadana fijado en la Ley Orgánica 2/1986, de 13 de marzo, de Fuerzas y Cuerpos de Seguridad. Se trata del supuesto de atentado previsto en el artículo 554.3.b) CP, cuyo tenor dispone:

"También se impondrán las penas de los artículos 550 y 551 a quienes acometan, empleen violencia o intimiden gravemente: [...]

b) Al personal de seguridad privada, debidamente identificado, que desarrolle actividades de seguridad privada en cooperación y bajo el mando de las Fuerzas y Cuerpos de Seguridad».

En pocas palabras, este art. 554.3.b) introduce en nuestro Código un delito «autónomo» de atentado contra el personal de seguridad privada que plantea numerosos problemas interpretativos, el mayor de los cuales será objeto predilecto de este artículo: las modalidades comisivas.

Lo cierto es que este delito no ha sido aplicado de momento por los tribunales ${ }^{3}$. Sin embargo, el entramado jurídico para que el personal de

1 Se trata de los supuestos de atentado contra "fuerza armada» (antiguo art. 554), que solo preveía la modalidad comisiva de resistencia activa grave, y atentado contra las personas que acuden en auxilio de los sujetos pasivos del atentado "clásico» (antiguo art. 555), que preveía las conductas típicas de acometimiento e intimidación.

2 Se trata de los supuestos de atentado contra los bomberos o miembros del personal sanitario o equipos de socorro (art. 554.3.a) CP) y contra el personal de seguridad privada (art. 554.3.b) CP).

3 En realidad, la SAP-Barcelona, Sección 3. a, 151/2016, de 23.3, entró fugazmente a interpretar el precepto, aunque solo para afirmar su aplicabilidad frente al art. 550.1 CP, que fue la norma usada por el tribunal de instancia para condenar al recurrente que golpeó a un agente de seguridad privada de la estación de Sants. 
seguridad privada participe en cooperación y bajo el mando de las Fuerzas y Cuerpos de Seguridad en actividades de seguridad ciudadana, y con ello se produzcan las primeras situaciones susceptibles de subsumirse en el art. 554.3.b) CP, ya se encuentra listo. Todo parece indicar además que el modelo de gestión público-privada de la seguridad ciudadana ha llegado para quedarse. A la espera de la aprobación del nuevo reglamento de seguridad privada, analizaremos en primer lugar las principales vigas que sostienen este armazón.

En segundo lugar abordaremos la difícil concreción del bien jurídico protegido por el delito de atentado contra el personal de seguridad privada, algo imprescindible para la posterior exégesis de sus concretos elementos típicos. Ello nos llevará a una lectura sistemática en la que será obligado detenerse en conceptos como el orden público y la seguridad ciudadana, así como en el bien jurídico protegido por el delito de atentado «clásico».

En tercer lugar, entrando ya en el examen de los elementos objetivos del art. 554.3.b) CP, nos centraremos en justificar la pretendida «autonomía» del delito de atentado contra el personal de seguridad privada frente al delito de atentado "clásico», así como en ponderar la trascendencia de este hecho para el análisis ulterior. Para ello nos familiarizaremos con el precepto, que examinamos en tres pasos.

Por último, abordaremos el principal problema que plantea la aplicación del art. 554.3.b) CP: la intrincada configuración de sus modalidades comisivas.

\section{La Ley 5/2014, de 4 de abril, de Seguridad Privada}

En enero de 2012, recién inaugurada la X legislatura, el señor Fernández Díaz compareció ante la Comisión de Interior del Congreso de los Diputados para exponer las líneas estratégicas y el programa de trabajo del Ministerio del Interior ${ }^{4}$. Dentro de la octava línea estratégica, dedicada a las actuaciones de «racionalización de medios y efectivos», el ministro anunció: "En un período de esfuerzo presupuestario como el presente, en el que la generación de recursos humanos y materiales va a ser limitada [...] pretendemos reformar la Ley de seguridad privada para establecer mecanismos de colaboración más eficaces con la seguridad pública, adaptarnos a la normativa europea y mejorar, en la medida de lo posible, como es nuestro deber, la cali-

${ }^{4}$ Para consultar el programa completo expuesto por el ministro, véase el Diario de Sesiones del Congreso de los Diputados, Comisión de Interior, sesión núm. 2 (extraordinaria) de 31 de enero de 2012 (http://www.congreso.es/public_oficiales/L10/CONG/DS/CO/ CO_029.PDF). 
dad del servicio» ${ }^{5}$. Al margen del mensaje, cristalino como pocos, esta parece ser la primera vez que en sede parlamentaria se reconoce a la seguridad privada como parte integrante de la estrategia de seguridad pública ${ }^{6}$. Si bien en la práctica, aquella ya llevaba décadas siendo un elemento cada vez más importante - a la par que polémico ${ }^{7}$, y sin duda auspiciado por grandes intereses económicos ${ }^{8}$ - en el desempeño efectivo de la función pública de seguridad ${ }^{9}$.

Tras dos escasos años de esta sesión entraría en vigor la Ley 5/2014, de 4 de abril, de Seguridad Privada (en adelante LSP), norma que introdujo grandes novedades respecto de su predecesora (la Ley 23/1992, de 30 de julio, de Seguridad Privada, en adelante Ley 23/1992). Entre otras, una novedosa clasificación de las tareas asignadas a la seguridad privada

5 Diario de Sesiones, ibid., p. 9.

6 Véase Gándara Trueba, E.: «La Ley 5/2014, de 4 de abril, de Seguridad Privada», Seguridad y ciudadanía: Revista del Ministerio del Interior, núm. 14, julio-diciembre 2015, p. 17.

7 Recuérdese que hasta la promulgación de la Ley 23/1992, de 30 de julio, de Seguridad Privada (en adelante, Ley 23/1992), se venían prestando sin respaldo legal alguno toda una serie de servicios de seguridad privada, como la protección personal o escolta por vigilantes jurados, armados y sin uniforme, o los prestados por los «guardas de seguridad» (vigilantes jurados no previstos en la normativa sobre seguridad privada pero que, de conformidad con los convenios colectivos de las empresas de seguridad, desempeñaban «tareas de vigilancia preventiva en general, excepto aquellas que reglamentariamente correspondan de modo exclusivo al Vigilante Jurado»). Al respecto, véase AGIRREAZKUENAGA ZigORRAGA, I.: «Perfiles y problemática de la seguridad privada en el ordenamiento jurídico español», Revista de Administración Pública, núm. 118, enero-abril 1989, pp. 125-128. Por su parte, en la actualidad se plantean análogas dudas legales respecto de otros servicios como la vigilancia y protección de edificios e instalaciones públicas (véanse IzQUIERDO CARRASCO, M.: «La noción y los servicios de seguridad privada», RCSP, núm. 16, 2006, pp. 95-96; Agirreazkuenaga Zigorraga, ibid., pp. 132-133; Barcelona Llop, J.: Policía y Constitución, Ed. Tecnos, Madrid, 1997, p. 139, y el mismo, «La administración de la seguridad ciudadana. Selección de problemas a comienzos del siglo XXI», Revista Vasca de Administración Pública, núm. 64, 2002, pp. 74-75).

8 Ya en 1987, el entonces subdirector operativo de la Policía Nacional, Agustín Linares, reconocía en El País ( Sancionadas este año 80 empresas de seguridad con 22 millones en total por numerosas irregularidades», 1.11 de 1987, en prensa) la existencia de «fuertes presiones» al Ministerio del Interior para la legalización de los escoltas privados, medida que finalmente se adoptó mediante la Ley 14/2000, de 29.12, de medidas fiscales, administrativas y del orden social, que añadió a la Ley 23/1992 una Disposición adicional quinta: «La Secretaría de Estado para la Seguridad del Ministerio del Interior podrá autorizar la prestación de funciones de acompañamiento, defensa y protección, por parte de los escoltas privados, de personas que tengan la condición de autoridades públicas, cuando las circunstancias lo recomienden». En la actualidad, los periodistas Roberto R. Ballesteros y Marina Valero informan desde El Confidencial sobre las presuntas relaciones entre la cúpula política y las grandes empresas de seguridad privada.

9 En 2012 el propio Gándara TRUebA, a la sazón Comisario Jefe de la Unidad Central de Seguridad Ciudadana de la Policía Nacional, se expresaba así en la presentación del programa Red Azul: «Con Red Azul el Cuerpo Nacional de Policía habla de tú a tú a la Seguridad Privada española. Reconoce su insustituible aportación al trabajo de la Seguridad Nacional, y la considera como su principal compañero de viaje para el cumplimiento de su misión constitucional de «proteger y servir» a los españoles». Véase «Plan integral de colaboración Red Azul», Segurpri, monográfico núm. 17, marzo 2012, p. 5. 
en actividades, funciones y servicios que no siempre clarifica las $\operatorname{cosas}^{10}$. En general, una idea recorre este catálogo de actividades (art. 5.1 LSP): se trata siempre de actividades relacionadas con la función pública de seguridad ciudadana cuyo desempeño, por diversas razones ${ }^{11}$, se encomienda legalmente a las empresas de seguridad privada. Esta es, en el fondo, la razón de ser de la LSP: regular un marco jurídico bajo el cual actores privados puedan participar en esa función pública. De lo contrario, ¿quién no calificaría de excesivo el régimen jurídico de un sector económico que prevé la injerencia de los agentes públicos, así como el inmediato deber de obediencia y colaboración con ellos, en prácticamente cualquier rincón de su ámbito material de actuación? El personal de seguridad privada está obligado, entre otras cosas, a obedecer en todo momento y a seguir las instrucciones de las Fuerzas y Cuerpos de Seguridad, incluso en el ámbito de las actividades de seguridad privada (art. 8.2 LSP), así como a comunicar a las mismas «tan pronto como sea posible» las informaciones de que tengan conocimiento y que sean relevantes "para la prevención, el mantenimiento o restablecimiento de la seguridad ciudadana» (art. 14.2 LSP). También da buena cuenta de esta naturaleza eminentemente pública la regulación de ciertas actividades, como las de los arts. 5.1.c), 5.1.d) y 5.1.e) $\mathrm{LSP}^{12}$, que razonablemente

10 En efecto, el esquema es a menudo farragoso. De un lado, las actividades de seguridad privada (art. 5.1 LSP) designan las categorías generales de cometidos a los que resultan de aplicación la LSP y su reglamento; los servicios (arts. 38 a 50 LSP) desagregan cada actividad de seguridad privada en sus posibles expresiones concretas - v.g., el art. 41 LSP especifica los servicios tasados que integran la actividad de vigilancia y protección (art. 5.1.a) LSP)_; y las funciones clasifican las actividades según el colectivo profesional al que se encomiendan, lo cual las solapa a menudo con los servicios - -v.g., corresponde a los vigilantes de seguridad «proteger el almacenamiento, recuento, clasificación, transporte y dispensado de dinero» (art. 32.1.c) LSP), función que se corresponde con los servicios de «vigilancia y protección sobre acciones de manipulación o utilización de bienes [...] valiosos que hayan de tener lugar en las vías o espacios públicos o de uso común» (art. 41.1.a) LSP) o de «retirada y reposición de fondos en cajeros automáticos, así como la prestación de servicios de vigilancia y protección de los mismos durante las citadas operaciones» (art. 41.1.b) LSP), ambos dentro a su vez de la actividad de «vigilancia y protección de bienes» (art. 5.1.a) LSP)—.

11 Resulta interesante comparar la justificación dada por el ministro Fernández Díaz al respecto («la racionalización de medios y efectivos») con la del profesor AGIRREAzKUENAGA ZIGORRAGA ya en 1989, cuando aún ni siquiera existía ley de seguridad privada: «Está claro que el Estado se ve impotente para garantizar con sus exclusivos medios la seguridad demandada por los ciudadanos, y se encuentra obligado a ceder parte del monopolio en el uso de la fuerza, que ostenta, en organismos privados cuya tutela deberá ser ejercida por los órganos competentes de las Fuerzas y Cuerpos de Seguridad». Véase AgIRREAZKUENAGA ZigORRAGA, ibid., p. 104.

12 «Constituyen actividades de seguridad privada las siguientes: [...] c) El depósito, custodia, recuento y clasificación de monedas y billetes, títulos-valores, joyas, metales preciosos, antigüedades, obras de arte u otros objetos que, por su valor económico, histórico o cultural, y expectativas que generen, puedan requerir vigilancia y protección especial. d) El depósito y custodia de explosivos, armas, cartuchería metálica, sustancias, materias, mercancías y cualesquiera objetos que por su peligrosidad precisen de vigilancia y protección especial. e) El transporte y distribución de los objetos a que se refieren los dos párrafos anteriores». 
reservan a empresas de seguridad el depósito, custodia y transporte de ciertos objetos que precisan «vigilancia y protección especial», obligando al usuario a contratar dichos servicios en ciertos $\operatorname{casos}^{13}$. Estas normas resultan doblemente elocuentes: marcan los umbrales a partir de los cuales la actividad correspondiente puede afectar a la seguridad ciudadana, $\mathrm{y}$, acto seguido, atribuyen su desempeño al personal de seguridad privada. En definitiva, a poco que se observe por separado cada actividad del art. 5.1 LSP se tropieza siempre con la tutela de intereses propios de la seguridad ciudadana (¿por qué, si no, se regula el transporte de sustancias explosivas y no el de los enseres de una mudanza?).

Por otro lado, puesto que las empresas están habilitadas para participar en una función pública, el Legislador se ha encargado, eso sí, de fijar taxativamente cómo deben realizarse tales actividades. En este sentido, prácticamente todos los extremos de cada servicio se encuentran regulados: desde la indumentaria del personal de seguridad privada ${ }^{14}$ o librosregistro obligatorios sobre comunicaciones con las Fuerzas y Cuerpos de Seguridad ${ }^{15}$, hasta el número de vigilantes en los inmuebles destinados a depósito, custodia y tratamiento de objetos ${ }^{16}$, o vehículos a utilizar en el transporte de los mismos ${ }^{17}$. La conclusión que se alcanza es siempre la misma: el Estado ha permitido al sector privado ocuparse de ciertas actividades ${ }^{18}$ que por mandato constitucional corresponderían a las Fuerzas

13 A este respecto, véase por ejemplo el art. 21.3 de la Orden INT/314/2011, de 1 de febrero, sobre empresas de seguridad privada, que establece que si el valor de lo transportado excede de cierta cuantía el transporte debe realizarse obligatoriamente a través de una empresa de seguridad autorizada para dicha actividad. O el art. 120.1.a) del Real Decreto 2364/1994, de 9 de diciembre, por el que se aprueba el Reglamento de Seguridad Privada (en adelante RSP), que obliga a los establecimientos u oficinas de las entidades de crédito donde se custodien fondos o valores a instalar «equipos o sistemas de captación y registro, con capacidad para obtener las imágenes de los autores de los delitos contra las personas y contra la propiedad», lo cual se relaciona con las actividades de los arts. 5.1.f) y 5.1.g) LSP.

14 Art. 39.2 LSP, art. 87.1 RSP y arts. 22 a 25 de la Orden INT/318/2011, de 1 de febrero, sobre personal de seguridad privada.

${ }_{15}$ Art. 19.1.b) RSP y Resolución de la Secretaría de Estado de Seguridad de 16 de noviembre de 1998, por la que se aprueban los modelos oficiales de libros-registro que se establecen en el Reglamento de Seguridad Privada.

16 Art. 20 de la Orden INT/314/2011.

17 Arts. 1.1.d) y 18 RSP y arts. 10 y 11 de la Orden INT/314/2011.

18 Y no solo actividades, sino que el sector también tiene voz en fase de diseño de las políticas públicas de seguridad. En este sentido, la Disposición adicional tercera del RSP (apartado 1) y la Orden INT/315/2011, de 1 de febrero (que derogó la Orden de 26 de junio de 1995) regulan la organización y funcionamiento de las «Comisiones de coordinación». La estructura orgánica se replica en cada nivel territorial: la Comisión Nacional, por ejemplo, es presidida por el Director General de la Policía y de la Guardia Civil y forman parte de la misma, entre otros, representantes de las federaciones y asociaciones de empresas de seguridad o de los establecimientos obligados a disponer de las medidas de seguridad, los sindicatos del personal de seguridad privada, hasta cinco expertos de reconocido prestigio e incluso un representante de la Federación Española de Municipios y Provincias. Observando asimismo las funciones de este órgano se trasluce definitivamente que esa 
y Cuerpos de Seguridad (art. 104.1 CE), e intenta asegurarse de que sean rectamente desempeñadas.

No procede aquí entrar en cada una de las actividades del art. 5.1 LSP. Pero sí cabe referirse a los servicios de vigilancia y protección (art. 41 LSP), los más estrechamente vinculados al objeto de este trabajo. Este art. 41 enumera los servicios concretos en que se materializa la actividad de seguridad privada de «vigilancia y protección de bienes, establecimientos, lugares y eventos, tanto públicos como privados, así como de las personas que pudieran encontrarse en los mismos» (art. 5.1.a) LSP), actividad encomendada en exclusiva a los vigilantes de seguridad (art. 32.1.a) LSP) y a los guardias rurales (art. 34.1 LSP). Una de las novedades más significativas de la LSP es, precisamente a través de su art. 41, la considerable ampliación del número de servicios que pueden prestarse en el exterior de los inmuebles. Junto a los enumerados en el apartado 1, que pueden prestarse sin necesidad de autorización previa (y que, salvo uno de ellos, ya se encontraban en el RSP ${ }^{19}$ ), los apartados 2 y 3 incluyen supuestos de nuevo cuño: en el apartado 2, los servicios de vigilancia y protección que requieren «autorización previa por parte del órgano competente», que además han de prestarse «en coordinación, cuando proceda, con las Fuerzas y Cuerpos de Seguridad» ${ }^{20}$, y en el apartado 3 los supuestos cuya prestación no depende ya de autorización administrativa sino de que "así se decida por el órgano competente», debiendo en todo caso realizarse «cumpliendo estrictamente las órdenes

"coordinación» a la que tanto aluden la LSP y el RSP se refiere a aspectos como el intercambio de experiencias de los distintos sectores, la información sobre los planes de prevención de la delincuencia o la propuesta de criterios de actuación conjunta del personal de seguridad privada con las Fuerzas y Cuerpos de Seguridad (apartados c), g) y f) del art. 4.1 de la Orden INT/315/2011, respectivamente).

19 La correspondencia entre ambas normas es la siguiente: el art. 41.1.a) LSP equivale al art. 79.1.b) RSP; el art. 41.1.b), al art. 79.1.f); el 41.1.c), al 79.1.g); el 41.1.f), al 79.1.d); y el 41.1.g), al 79.1.e). Por su parte, el servicio contenido en el art. 79.1.a) RSP (transporte de seguridad) se ha reconducido al art. 45 LSP (ámbito de la actividad contenida en el art. 5.1.e) LSP), y el del art. 79.1.c) RSP (verificación de alarmas y respuesta a las mismas), al art. 47.1 LSP (ámbito del art. 5.1.g) LSP). En puridad, el único servicio introducido por el art. 41.1 LSP que no contemplara ya el art. 79.1 RSP es el de ronda o vigilancia discontinua, consistente «en la visita intermitente y programada a los diferentes puestos de vigilancia establecidos o a los distintos lugares objeto de protección» (art. 41.1.e). Por último, el art. 41.1.h) ( «los servicios de vigilancia y protección a los que se refieren los apartados siguientes») no aporta nada, pues carece de todo sentido que tales servicios referidos en los apartados 2 y 3 puedan prestarse sin necesidad de autorización previa, cuando los propios apartados dicen lo contrario.

${ }^{20}$ Se trata de los siguientes servicios: «a) La vigilancia en polígonos industriales y urbanizaciones delimitados, incluidas sus vías o espacios de uso común. b) La vigilancia en complejos o parques comerciales y de ocio que se encuentren delimitados. c) La vigilancia en acontecimientos culturales, deportivos o cualquier otro evento de relevancia social que se desarrolle en vías o espacios públicos o de uso común, en coordinación, en todo caso, con las Fuerzas y Cuerpos de Seguridad. d) La vigilancia y protección en recintos y espacios abiertos que se encuentren delimitados». 
e instrucciones de las Fuerzas y Cuerpos de Seguridad ${ }^{21}$. De entre estos últimos destaca el ubicado en el art. 41.3.d) LSP, que puede considerarse una auténtica «cláusula de cierre» en tanto que su tenor literal admite la participación en cualquier servicio encomendado a la seguridad pública.

En resumen, el art. 41 LSP establece tres regímenes de realización de ciertos servicios de vigilancia y protección, cada uno fijando un grado de autonomía del personal de seguridad privada en la prestación y una forma de acceso por las empresas a la realización de tales servicios. Apréciese que el régimen progresivamente restrictivo de cada apartado corre en paralelo a la más intensa intervención del personal de seguridad privada en las funciones propias de las Fuerzas y Cuerpos de Seguridad. A medida que nos acercamos al núcleo de la seguridad ciudadana, la participación del personal de seguridad privada se vuelve más puntual y restringida.

Por otro lado, los servicios incluidos en los arts. 41.2 y 41.3 LSP parecen ser los únicos de toda la LSP que prevén una actuación conjunta del personal de seguridad privada con las Fuerzas y Cuerpos de Seguridad. Esta circunstancia es relevante pues, como se verá a lo largo del trabajo, uno de los elementos objetivos del tipo contenido en el art. 554.3.b) CP es precisamente el desempeño de una actividad de seguridad privada «en cooperación y bajo el mando de las Fuerzas y Cuerpos de Seguridad». Baste ahora decir que conforme a la LSP la inmensa mayoría de atentados contra el personal de seguridad privada se verificará durante el desempeño de los servicios de los arts. 41.2 y 41.3 LSP.

\section{Bien jurídico protegido en el art. 554.3.b) del Código Penal}

Bajo la rúbrica «Delitos contra el orden público» el legislador de 1995 agrupó en el Título XXII del Código toda una mezcolanza de figuras delictivas que, quizá más por inercia histórica que por coherencia, venían agremiándose bajo el mismo Título en códigos precedentes ${ }^{22}$. Desde la

21 Enumera este precepto los siguientes: «a) La vigilancia perimetral de centros penitenciarios. b) La vigilancia perimetral de centros de internamiento de extranjeros. c) La vigilancia de otros edificios o instalaciones de organismos públicos. d) La participación en la prestación de servicios encomendados a la seguridad pública, complementando la acción policial. La prestación de estos servicios también podrá realizarse por guardas rurales».

22 Lo que hoy entendemos por «delitos contra el orden público» es el producto de una larga inercia que mantiene bajo la misma rúbrica un conjunto abigarrado de figuras delictivas. Centrados en el delito objeto de estudio, el atentado osciló a lo largo de los códigos decimonónicos y del primer tercio del siglo xx por diversos capítulos, siempre dentro del mismo Título III. En el Código de 1822, este título recibía la rúbrica «De los delitos contra la seguridad interior del Estado, y contra la tranquilidad y orden público»; como puede verse, el atentado ya nace ligado a la noción de orden público. La denominación se acortó en el Código de 1848 ( «Delitos contra la seguridad interior del Estado y el orden público») 
LO $1 / 2015$, una de estas figuras es el delito de atentado contra el personal de seguridad privada. Partiendo de que la ubicación sistemática de un delito nunca lo dice todo sobre el bien jurídico por él tutelado, no puede negarse que siempre nos revela algo sobre el mismo. Así, la expresión "orden público» no puede entenderse aquí como mera rúbrica de un Título sino como un verdadero concepto material que vincula, define y acota al menos en cierta medida los respectivos bienes jurídicos protegidos a lo largo del Título XXII. En buena lógica con ello, este epígrafe estudia la relación entre el bien jurídico tutelado por el art. 554.3.b) CP con el concepto de orden público.

El orden público es uno de los conceptos jurídicos más escurridizos de todo el ordenamiento ${ }^{23}$. Explican este carácter, entre otros motivos, sus notorias amplitud y vaguedad, su conexión directa con la cambiante realidad social o su evidente interés político, factores que han permitido a cada época darse, por medio del soberano de turno, su propia noción del orden público - y aun dentro de cada época, diversas nociones del mismo-. Dada la complejidad del tema, no se aborda aquí la evolución del concepto de orden público sino directamente su concepción en ${ }^{24}$ la CE. En vistas de este objetivo, habrá de esbozarse en primer lugar el esquema trazado por esta en materia de seguridad.

Ciertamente, en España el orden público se ha resistido desde antiguo a ejercer como verdadero concepto material. La presencia endémica del militarismo en nuestra vida social ${ }^{25}$, la percepción histórica general de que seguridad y orden público son nociones definidas e impuestas unilateralmente desde el poder y una confusión no menos general entre las labores policiales de seguridad ciudadana y las de investigación de delitos ${ }^{26}$

para pasar en 1870 directamente a «Delitos contra el orden público», divisa que no abandonaría hasta el Código de 1944. Este trocó el histórico Título III por un hipertrofiado Título II al que se denominó «Delitos contra la seguridad interior del Estado». La rúbrica se mantuvo intacta con el Código de 1973, y finalmente el Código de 1995 recuperó el añejo "Delitos contra el orden público», trasladándolo al título XXII; en la actualidad, el atentado comparte su Capítulo II junto con los delitos de resistencia y desobediencia.

${ }^{23}$ Por todos, véase Izu Belloso, M.J.: «Los conceptos de orden público y seguridad ciudadana tras la Constitución de 1978», Revista Española de Derecho Administrativo, núm. 58, abril-junio 1988, p. 2, así como la serie de publicaciones allí citadas.

${ }^{24}$ Que no a partir de la Constitución, pues aún la trasnochada STS de 18.7 de 1984 sostenía que «[e]l orden público descansa en los principios de subordinación y respeto de los gobernados a los gobernantes y en la paz pública, es decir en la existencia de un mínimum de tranquilidad, serenidad y seguridad, indispensable en un estado de derecho, para que los ciudadanos puedan ejercer sus derechos o cumplir sus obligaciones en un ambiente de libertad y respeto mutuo» (la cursiva es mía).

25 Para Parejo Alfonso, un eco de tan prolongada presencia aún luce en la expresión constitucional «Fuerzas y Cuerpos de Seguridad del Estado» (art. $104 \mathrm{CE}$ ), así como en las legales «Instituto Armado de naturaleza civil» (art. 9.a) LOFCS) e «Instituto Armado de naturaleza militar» (art. 9.b LOFCS). Véase PAREJo ALFONSO, L.: Seguridad pública y policía administrativa de seguridad, Ed. Tirant lo Blanch, Valencia, 2008, p. 24.

26 Parejo Alfonso, ibid., p. 27. 
ayudan a explicar la situación. En este sentido, el período constitucional ha permitido al fin el desarrollo de una noción sustantiva de orden público, es decir, una no definida libremente por el poder constituido sino construida a partir de los valores constitucionales del Título Primero. Asimismo, la legislación democrática ha contribuido a distinguir entre las tareas otrora superpuestas de protección de la seguridad ciudadana y tutela del orden jurídico-penal, lo cual ha permitido concebir una función pública de seguridad basada en (y defensora de) los principios constitucionales ${ }^{27}$. De ambas situaciones se extrae algo común: los derechos fundamentales aportan criterios básicos para delimitar opciones constitucionalmente válidas de convivencia ${ }^{28}$. En este caso, para perfilar la noción constitucional de orden público resulta obligado partir del derecho fundamental a la seguridad personal (art. $17 \mathrm{CE}$ ).

\subsection{Seguridad personal, pública y ciudadana en la Constitución}

La CE no define la seguridad personal ${ }^{29}$. Para PAREJo Alfonso se entiende como el «estado de normalidad mínima (en sentido material

27 Parejo Alfonso, ibid., pp. 52-53.

28 Ello porque, como señala RIDAURA MarTínEz, «los derechos fundamentales, en cuanto proyecciones de núcleos esenciales de la dignidad de la persona, se erigen en los fundamentos del propio Estado de Derecho democrático y no pueden ser menoscabados (STC 194/1994, de 28.6) [...] el Tribunal Constitucional español ha reconocido que la Declaración de Derechos de nuestra Constitución se acoge a la Teoría Dualista sobre los derechos fundamentales, que superando la noción estrictamente subjetivista, les dota de una fuerza expansiva que impregna la aplicación de toda la legislación y, en definitiva, el funcionamiento del entero ordenamiento jurídico [...]. Así, en la Sentencia de 14.7 de 1981, afirmará que: 1) «en primer lugar, los derechos fundamentales son derechos subjetivos, derechos de los individuos, no solo en cuanto derechos de los ciudadanos en sentido estricto, sino en cuanto garantizan un estatus jurídico o la libertad de un ámbito de la existencia. 2) Pero, al propio tiempo, son elementos esenciales del ordenamiento jurídico objetivo de la comunidad nacional, en cuanto esta se configura como marco de una convivencia humana, justa y pacífica, plasmada históricamente en un Estado de Derecho, en un Estado Social y democrático de derecho». [...] en consecuencia, el principio "favor libertatis» se convertirá en parámetro de interpretación, de tal forma que la legalidad ordinaria habrá de interpretarse de la forma más favorable para la efectividad de tales derechos (STC 17/1985, de 9 de febrero)» (Seguridad privada y Derecho fundamentales, Ed. Tirant lo Blanch, Valencia, 2015, pp. 119-120).

${ }_{29}$ Como tampoco define la libertad personal. El Tribunal Constitucional (por todas, SSTC 15/1986, de 31.1, 98/1986, de 10.7, y 341/1993, de 18.11) establece que la seguridad personal «comporta o implica la ausencia de perturbaciones procedentes de medidas tales como la detención u otras similares [...] adoptadas arbitraria o ilegalmente», mientras que la libertad personal consiste en «la libertad de toda persona de organizar en cualquier momento y lugar [...] su vida individual y social con arreglo a sus propias opciones y convicciones». A este respecto, señala PAREJO ALFOnso (remitiéndose a los trabajos de GARCía MORILlO) que tales definiciones suponen «despojar la libertad personal de toda protección constitucional frente a acciones que no comporten la privación de libertad, tales como las intimidaciones, las retenciones, los cacheos [...]. Pues si la libertad personal solo garanti- 
o real) precisa para la efectividad de los derechos y las libertades de la persona ${ }^{30}$, definición que se cohonesta con la doctrina del Tribunal Europeo de Derechos Humanos al respecto ${ }^{31}$. Este derecho, como todos los contenidos en la CE, exige una prestación para su compleción por parte de los poderes públicos ${ }^{32}$, responsables universales - que no únicos-de las condiciones de vida del individuo (art. 9.3 CE). Así, las prestaciones de seguridad personal dirigidas a cada ciudadano se agregan en un más amplio concepto de seguridad pública ${ }^{33}$, cuya normación corresponde en exclusiva al Estado (art. 149.1.29. ${ }^{a}$ CE) y su ejecución, al menos en parte $^{34}$, a la Administración (art. 104.1 CE). De la relación entre este par de preceptos pueden extraerse ya varias claves.

za frente a la privación de libertad, todo cuanto no alcance ese grado de incidencia queda fuera del radio de acción de tal garantía» (ibid., p. 35). Sin embargo, el Tribunal Constitucional sí ha considerado la medida de identificación en dependencias policiales como una privación de libertad a los efectos del art. 17.1 CE (por todas, SSTC 341/1993, de 18.11, 22/1988, de 18.2, y 178/1985, de 19.12).

30 Parejo Alfonso, ibid., p. 31.

31 Puesto que la estructura del art. $17 \mathrm{CE}$ es prácticamente idéntica a la de los arts. 5 CEDH y 9 del Pacto Internacional de Derechos Civiles y Políticos (normas que, por cierto, integran el canon de interpretación de los derechos fundamentales ex art. 10.2 CE), cabe extrapolar la doctrina del Tribunal Europeo de Derecho Humanos al respecto (por todas,

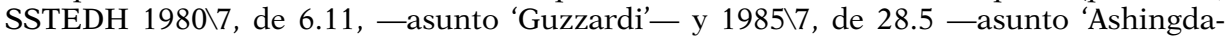
ne'-) y por consiguiente afirmar que las afecciones a la libertad personal consistentes en la detención o prisión quedan cubiertas por las garantías de los arts. $17 \mathrm{CE}, 5 \mathrm{CEDH}$ y 9 PIDCP in toto, mientras que las afectaciones al margen de la detención lo están por las de los apartados 1 de los respectivos preceptos.

32 En este sentido véase de nuevo PAREJo Alfonso, para quien la competencia de seguridad pública (art. 149.1.29. ${ }^{\text {a }} \mathrm{CE}$ ) constituye «desde la básica perspectiva del Estado social y democrático de Derecho (art. 1.1 CE) y de la responsabilización del Estado en las condiciones de la vida social que este supone, un deber constitucional positivo [...] el Estado está constitucionalmente obligado a realizar, en el marco de la legalidad, un orden público (una seguridad pública real) que efectivamente responda al más general orden constitucional» (ibid., p. 46). A este respecto, apuntala MARTín-RETORTILLO BAQUER (probablemente pensando en el art. 12 de la Declaración de los Derechos del Hombre y del Ciudadano, de 26 de agosto de 1789) que «las reglas y criterios de Derecho constitucional, al diseñar cada uno de los derechos y libertades, van a necesitar el auxilio de las reglas y criterios del Derecho administrativo [...] para hacerse efectivos» («Derechos fundamentales y vía pública», Revista andaluza de Administración Pública, núm. 91, 2015, p. 19).

33 A falta de definición en la $\mathrm{CE}$, la seguridad pública es perfilada jurisprudencialmente como la actividad «dirigida a la protección de personas y bienes (seguridad en sentido estricto) y al mantenimiento de la tranquilidad $\mathrm{u}$ orden ciudadano, que son finalidades inseparables y mutuamente condicionadas» (STC 33/1982, de 8.6). Se trata, por lo tanto, de «un conjunto plural y diversificado de actuaciones, distintas por su naturaleza y contenido, aunque orientadas a una misma finalidad tuitiva del bien jurídico así definido. Dentro de este conjunto de actuaciones hay que situar [...] las específicas de las organizaciones instrumentales destinadas a este fin y, en especial, las que corresponden a los Cuerpos y Fuerzas de Seguridad a que se refiere el artículo 104 de la CE» (STC 104/1989, de 8.6). Es por ello que BARCELONA LLOP califica la seguridad pública de concepto «ultrapolicial», «delimitador de competencias y no descriptivo de los cometidos de las Fuerzas y Cuerpos de Seguridad, aunque en ocasiones se refiera directamente a estas» (Policía y..., ibid., p. 223).

${ }^{34}$ En lo que se refiere a «proteger el libre ejercicio de los derechos y libertades y garantizar la seguridad ciudadana» (art. 104.1 CE). 
La primera: la seguridad es concebida constitucionalmente como una función pública ${ }^{35}$ - concepto por lo demás no exento de problemática ${ }^{36}$. Puesto que la mera existencia de derechos y libertades no asegura sin más su eficacia, se hace necesario e igualmente responsabilidad del Estado corregir las eventuales perturbaciones de aquel ${ }^{37}$. Esta lectura nos acerca al carácter universal de la noción de seguridad, concepto reacio a ser encorsetado como «sector» de la realidad en tanto que no pueden serlo las infinitas perturbaciones que le acechan.

35 A este respecto resulta nítida como pocas RidAuRA MARTínez: «no consideramos que pueda hablarse de la seguridad ciudadana [la autora utiliza seguridad ciudadana y pública como intercambiables] como un servicio público; pues hablar de servicio público implica la prestación de una actividad que, en principio, no es ni pública ni administrativa; se convierte en pública cuando el legislador la reserva para sí. Por el contrario, la seguridad ciudadana está reservada, constitucionalmente, en exclusiva, a la Administración pública, ya que es una función de soberanía. En consecuencia, no existirá la posibilidad de encomendar la gestión nuclear de la seguridad a agentes externos, de los que puede predicarse su colaboración y auxilio, pero no la asunción de las funciones que el texto constitucional encomienda en exclusiva a las Fuerzas y Cuerpos de Seguridad» (ibid., pp. 31 y 102).

36 En palabras de JaVATo Martín, «actualmente se defienden por la doctrina penal cuatro concepciones divergentes de función pública: la teleológica, o con más precisión teleológica-subjetiva, la objetiva, la subjetiva y la mixta o ecléctica» («Comentario al art. 24 CP», en Gómez Tomillo, M. (dir.): Comentarios al Código Penal, Ed. Lex Nova, Madrid, 2010, p. 226). Véase asimismo RAmón RiBas, E.R.: «La derogación jurisprudencial del artículo 24.2 CP (concepto de funcionario público)», Estudios penales y criminológicos, núm. 34, 2014, pp. 185-188. Da fe asimismo de este fragmentado criterio la jurisprudencia: véanse, por todas, las SSTS 186/2012, de 14.3 («son funciones públicas las realizadas por entes públicos, con sometimiento al Derecho Público y desarrolladas con la pretensión de satisfacer intereses públicos», 68/2003 («cualquier actuación de estas entidades [el Estado, las entidades locales y la administración institucional] donde exista un interés público responde a ese concepto amplio de función pública»), 866/2003, de 16.6 («lo verdaderamente característico y lo que les dota de la condición pública, es la función realizada dentro de un organigrama de servicio público») y 1292/2000, de 10.7 ( «lo relevante es que dicha persona esté al servicio de entes públicos, con sometimiento de su actividad al control del derecho administrativo y ejerciendo una actuación propia de la Administración Pública»). Frente a ellas, especialmente acertada nos parece la de función pública como «una relación de servicio a una Administración Pública con sumisión al Ordenamiento característico de esta —el Derecho Administrativo—》 (ÁLVAREZ García, F.J./CARrasco ANDrino, M.M: «Los nuevos sujetos pasivos de la acción en los delitos de atentado, resistencia y desobediencia y el artículo 24 del Código penal», en Álvarez García, F.J. (dir.): Tratado de Derecho penal español. Parte especial. V, Tirant lo Blanch, Valencia, 2018, p. 22 del original), en tanto que la sujeción al Derecho público parece ser uno de los últimos criterios efectivos para deslindar lo que es actividad pública de la mera gestión privada.

37 Esta es la idea que preside el Preámbulo de la LOPSC: «Las demandas sociales de seguridad ciudadana van dirigidas esencialmente al Estado, pues es apreciable una conciencia social de que solo este puede asegurar un ámbito de convivencia en el que se posible el ejercicio de los derechos y libertades, mediante la eliminación de la violencia y la remoción de los obstáculos que se opongan a la plenitud de aquellos». Todavía más clara al respecto se muestra la Exposición de motivos de la derogada Ley Orgánica 1/1992, de 21 de febrero, sobre Protección de Seguridad Ciudadana: «La protección de la seguridad ciudadana y el ejercicio de las libertades públicas constituyen un binomio inseparable». 
Segunda clave: la competencia exclusiva del Estado en materia de seguridad pública (art. 149.1.29. ${ }^{a} \mathrm{CE}$ ) incluye en principio la facultad de deslindar qué actividades concretas serán públicas y cuáles accesibles a sujetos privados ${ }^{38}$, si bien el art. 104.1 CE predetermina que han de ser públicas, en todo caso, las que tengan como misión «proteger el libre ejercicio de los derechos y libertades y garantizar la seguridad ciudadana». Estas actividades pueden considerarse el núcleo de la función pública de seguridad en tanto que implican la actualización de los límites inherentes al conjunto de derechos y libertades, tareas solo encomendables al titular del ius imperii ${ }^{39}$. Así, la seguridad ciudadana englobaría aquellas actividades de seguridad pública «que se insertan en el conjunto de los cometidos ordinarios y normales de las Fuerzas y Cuerpos de Seguridad ${ }^{40}$, las cuales, a juicio de CARRO FERNÁNDEZ-VALMAYOR, pueden reconducirse a la protección de personas y bienes frente a acciones violentas o agresiones, situaciones de peligro o calamidades públicas ${ }^{41}$.

Tercera clave: el derecho fundamental a la seguridad personal recibe su compleción en forma de acción policial de carácter preventivo, esto es, a través de la policía de seguridad. Lo cual no significa que toda protección de personas o bienes sea seguridad pública ${ }^{42}$, ni que la seguridad

38 Y ello es así porque la Constitución no prevé expresamente qué actividades deben por su naturaleza ser públicas o privadas; más bien, el deslinde entre ambas «es el resultado de una decisión del poder público competente que, aunque fruto de un amplio margen de apreciación, en modo alguno es libre [...] y se extiende legítimamente solo, al menos por lo que hace a las de carácter económico, hasta donde exija la satisfacción de dicho interés general» (PAREJo AlFonso, ibid., pp. 97-98).

${ }_{39}$ Mientras que la autotutela privada se circunscribiría a los casos de legítima defensa o estado de necesidad, es decir, previo ilícito penal. Al respecto, véase PAREJO ALFONSO, ibid., pp. 94 y 100. Sin embargo, parece contradecir el criterio constitucional el art. 1.4 LOFCS, cuando establece que «[e]l mantenimiento de la Seguridad Pública se ejercerá por las distintas Administraciones Públicas a través de las Fuerzas y Cuerpos de Seguridad» (la cursiva es mía).

40 Barcelona Llop, Policía y..., ibid., p. 238. Ocurre que ni la CE ni el Tribunal Constitucional definen la seguridad ciudadana (a salvo de la STC 325/1994, de 12.12, que no aporta demasiada luz al asunto), lo cual ha sembrado un amplio debate doctrinal. En contra del criterio aquí defendido, véanse por todos Izu Belloso, ibid., p. 12, que considera la seguridad pública y la ciudadana como sinónimas, así como el propio PAREJO ALFONSO, ibid., que utiliza ambos términos indistintamente. En todo caso, me atrevo a sugerir que de haber rezado la redacción del art. 104.1 CE «[...] proteger el libre ejercicio de los derechos y libertades y con ello garantizar la seguridad ciudadana» (como parece quererse expresar implícitamente), quizá no existiría tal polémica.

${ }^{41}$ CarRo Fernández-VALMaYor, J.L.: «Sobre los conceptos de orden público, seguridad ciudadana y seguridad pública», Revista Vasca de Administración Pública, núm. 27, 1990, p. 14. Abona esta tesis el hecho de que la LOPSC se refiera expresamente a los casos de "grave calamidad pública o catástrofe extraordinaria» como incluidos en la noción de seguridad ciudadana (arts. 7.2 y 15.2).

42 Pues, de lo contrario, prácticamente todo el ordenamiento caería directamente dentro de la seguridad pública y, por ende, en la competencia estatal del art. 149.1.29. ${ }^{a}$ CE. En este sentido, véase la STC 59/1985, de 6.5. Piénsese en campos como la Seguridad Social, la sanidad o el medio ambiente. 
pública sea solo policía de seguridad ${ }^{43}$ ni que toda la actividad de policía constituya seguridad pública ${ }^{44}$.

Y cuarta clave: el mandato del art. 104.1 CE opera a la vez como título habilitante y como límite al desempeño de la función pública de seguridad $^{45}$. En efecto, la policía de seguridad forma parte integrante de la Administración y por ello está sujeta a los principios jurídicos del art. 103.1 CE. En lo que aquí interesa, sus miembros deben servir a «los intereses generales» -intereses que en el ámbito concreto de la policía quedan definidos por el art. 104.1 CE («proteger el libre ejercicio de los derechos y libertades y garantizar la seguridad ciudadana») ${ }^{46}$ - , actuando siempre «con sometimiento pleno a la ley y al Derecho», circunstancia especialmente alusiva al estricto deber de observancia de los derechos y libertades establecido por la $\mathrm{CE}^{47}$.

\subsection{El orden público en la Constitución}

Sin embargo, ni rastro del orden público. Lo que por otro lado bien puede celebrarse en tanto que, como señala BARCELONA LLOP, «una no-

${ }^{43}$ Llegado el caso puede extenderse sobre ámbitos en principio externos como la salubridad, las catástrofes naturales, el medio ambiente o la protección civil, entre otros. Véanse al respecto las SSTC 117/1984, de 5.12, que reconduce a la seguridad pública los motivos graves de orden público del art. 421 LRL pese a que no guardan relación alguna con lo policial, «[d]e donde cabe inferir que la seguridad pública [...] no siempre tendrá que ver con la policía de seguridad» (BARCELONA Llop, ibid., p. 214); 133/1990, de 19.7, que incluye dentro de la seguridad pública a la protección civil, materia no circunscrita a las misiones policiales, y 104/1989, de 8.6: «por relevantes que sean [...] esos servicios policiales no agotan el ámbito material de lo que hay que entender por seguridad pública [...]. Otros aspectos y otras funciones distintas de los Cuerpos y Fuerzas de Seguridad, y atribuidas a otros órganos y autoridades administrativas [...] componen, sin duda, aquel ámbito material». En el mismo sentido, véase MaPelli CAFFARENA, ibid., p. 268.

${ }^{44}$ Piénsese en la policía administrativa, v.g., en los procedimientos de evaluación y control que garantizan el buen orden alimentario Sobre la distinción funcional y orgánica entre policía de seguridad y policía administrativa, véase por todos BARCELONA LLOP, Policía y..., ibid., p. 86.

${ }_{45}$ Pues los sujetos públicos, a diferencia de los particulares, solo pueden guiarse por intereses generales determinados legalmente - la desviación de poder constituye supuesto de nulidad radical-, y es precisamente la satisfacción del interés general la que determina, en cada caso, «el deslinde y los términos de la incorporación de una actividad al elenco de las públicas; términos que pueden ir desde la habilitación para la actuación del poder público (en concurrencia con la iniciativa privada) hasta la reserva de toda o parte de la actividad a favor de este» (PAREJo Alfonso, ibid., p. 98).

${ }_{46}$ Véase Barcelona Llop, Policía y..., ibid., pp. 101-102. Nótese la nada casual omisión del orden público en la delimitación de las funciones de las Fuerzas y Cuerpos de Seguridad, en contraste con lo útil que le resultaba a la normativa preconstitucional.

47 «Los derechos y libertades se sitúan, así, en el corazón mismo de la actividad policial, que no solo debe protegerlos frente a agresiones, sino que debe ser ella misma protectora de unos y otras» (BARCelona Llop, Policía y..., ibid., pp. 233-236). En el mismo sentido véase RidAURA MARTíneZ, ibid., pp. 26-28. 
ción de textura jurídica poco perfilada y proclive a la expansividad no es la más adecuada para referir los fines de la policía de seguridad» ${ }^{48}$. En efecto, el concepto de orden público no ha sido precisamente un dechado de ejemplaridad en nuestra historia reciente: definido de forma caprichosa, arbitraria y unilateral por el poder, no ha servido tradicionalmente más que para limitar derechos e imponer sanciones de forma indiscriminada ${ }^{49}$. Por el mismo motivo, su omisión en la actual regulación constitucional de la seguridad pública no puede reputarse de ningún modo como azarosa ${ }^{50}$ - solo aparece en la CE en dos ocasiones: como límite material al ejercicio de la libertad religiosa (art. 16.1 CE) y el derecho de manifestación (art. 21.2 CE) ${ }^{51}$.

El orden público como concepto jurídico ${ }^{52}$ posee varias acepciones, reconducibles básicamente a dos. Una es la restringida o material, identificada con una situación exterior de paz y tranquilidad públicas.

48 Barcelona Llop, Policía y..., ibid., pp. 197-198. El autor sentencia a renglón seguido que «[e]l de orden público, en definitiva, ha sido un concepto que ha servido para casi todo. Pero para casi todo lo que no puede ser de recibo en un Estado democrático de Derecho».

49 Por todos, véanse Izu Belloso, ibid., pp. 7-10, y Martín-Retortillo Baquer, L.: La cláusula de orden público como límite -impreciso y creciente- del ejercicio de los derechos, Ed. Civitas, Madrid, 1975, pp. 50-55, así como, de entre una larga serie, las sonrojantes SSTS de 23.3 de 1962, de 12.6 de 1965, y de 6.10 de 1967.

50 En efecto, los precedentes legislativos no pueden ser más claros: tanto la Ley 45/1959, de 30.7, de Orden Público (arts. cuarto y sexto.1) como la Ley Orgánica 1/1967, de 10.1, del Estado (art. 37) atribuían a las «Fuerzas de Seguridad del Estado» o «Fuerzas de Orden Público» la prevención, mantenimiento y restauración de la seguridad y orden públicos, previsión que a su vez traía causa de la Ley de 8.3 de 1941, de reorganización de los servicios de policía. Baste citar un extracto del Preámbulo de esta última, que establecía que este cuerpo debía «llevar a cabo la vigilancia permanente y total, indispensable para la vida de la Nación, que en los Estados totalitarios se logra merced a una acertada combinación de técnica perfecta y lealtad que permita la clasificación adecuada de sus actividades y dé vida a la Policía política, como órgano más eficiente para la defensa del Estado». Sobre la tramitación parlamentaria de los actuales arts. 104.1 y 149.1.29. ${ }^{a}$ CE en relación con el concepto de orden público, véase BARCElona Llop, Policía y..., ibid., pp. 200-205.

51 Véase Ridaura Martínez, ibid., pp. 24-25. Por otro lado, y restringiéndonos al llamado «bloque de constitucionalidad», los Estatutos de Autonomía del País Vasco (art. 17.1. ${ }^{\circ}$ ) y de Cataluña (art. 13.2.a) sí han echado mano del concepto de orden público al describir las finalidades o misiones de sus policías autonómicas, lo cual no deja de ser paradójico después de que, como señala CARRo Fernández-VALMAYOR, el constituyente rehuyese deliberadamente del concepto a la hora de describir la misión de las Fuerzas y Cuerpos de Seguridad (art. 104). Véase CARRo FERnáNDEZ-VALMAYor, ibid., p. 2.

${ }_{52}$ Es decir, construido él mismo a partir de conceptos jurídicos. No se entrará aquí, por lo tanto, en la concepción defendida por cierto sector histórico de la doctrina administrativa, sobre todo en Alemania, que distinguía la seguridad pública («öffenliche Sicherheit»), entendida como protección de bienes individuales y colectivos tutelados por el ordenamiento jurídico, del orden público («öffentliche Ordnung») como concepto metajurídico que engloba «el conjunto de las reglas de comportamiento no escritas, que son consideradas en la conciencia colectiva como indispensables para una vida en común ordenada». Véanse Parejo Alfonso, ibid., p. 58, así como Carro Fernández-Valmayor, ibid., p. 4. 
Esta fue la noción originaria en España ${ }^{53}$, la introducida en las Constituciones decimonónicas como cláusula de habilitación general —si bien de aplicación muy excepcional ${ }^{54}$ - en favor del Rey ${ }^{55}$, y la que inspiró la denominación «Fuerzas de Orden Público» durante la dictadura franquista (art. 37 de la Ley Orgánica 1/1967, de 10 de enero, del Estado). Y la otra es la noción amplia o formal, es decir, la que porta y sintetiza los principios jurídicos esenciales de la comunidad. Lo más parecido a esta noción en España fue la experiencia de la Ley de Orden Público de 28 de julio de 1933, que si bien ensanchaba la cláusula de orden público a prácticamente todo lo que alterase «materialmente la paz pública» ${ }^{56}$, tal precepto en blanco era interpretado en un Estado constitucional, esforzado por reconocer y asentar la pluralidad política y el juego de los derechos individuales y sociales y, sobre todo, donde la legalidad era amplia ${ }^{57}$. En lo que aquí interesa, su art. 3.4. ${ }^{\circ}$ establecía como actos contra el orden público «[1] os que no realizados por virtud de un derecho taxativamente reconocido por las leyes, o no ejecutados con sujeción a las mismas, se dirijan a perturbar el funcionamiento de las instituciones del Estado, la regularidad de los servicios públicos o el abastecimiento y servicios necesarios de las poblaciones». Sin embargo, no puede decirse lo mismo de la Ley franquista de 30 de julio de 1959, norma que, amén de su acérrimo apego a la metafísica, consagró la «trivialización» del concepto de orden público, hasta el punto de integrar en el mismo el normal funcionamiento de las instituciones privadas (art. 1) ${ }^{58}$.

${ }^{53}$ La identificación del orden público con la tranquilidad en la calle ya se apreciaba en el Discurso preliminar de presentación del Proyecto de Constitución, en 1812: «el soldado es un ciudadano que suspendiendo la tranquila e inocente ocupación de la vida civil va a proteger y conservar con las armas, cuando es llamado por la ley, el orden público en lo interior, y hacer respetar la nación siempre que los enemigos de afuera intenten invadirla u ofenderla» (la cursiva es mía). Véase Izu Belloso, ibid., p. 7.

54 Ya que «la Ley de orden público [de 23 de abril de 1870] constituye un ejemplo típico [...] de norma de vigencia latente: que está en la reserva, a la espera de que [...] las garantías constitucionales hubieran sido suspendidas y hubiera sido declarado lo que hoy se conoce con el nombre de estado de excepción» (MARTín-Retortillo BAQUER, La cláusula de..., ibid., p. 36).

${ }_{55}$ En palabras de Martín-Retortillo Baquer, el orden público de tradición decimonónica (cristalizado en la ley de 1870) se refiere a «revueltas, a asonadas, a motines, a levantamientos populares [...] por ello de aplicación excepcional, por quiebra grave del orden» (MARTín-RETORTILlo BAOUER, La cláusula de..., ibid., p. 41).

${ }^{56}$ Concretamente, el párrafo $6 .^{\circ}$ del art. 3 de la citada ley disponía: «Se reputarán en todo caso actos contra el orden público: [...] Los que de cualquier otro modo no previsto en los párrafos anteriores alteren materialmente la paz pública».

57 Véase Martín-Retortillo BaQuer, La cláusula de..., ibid., p. 47.

58 Véanse Izu Belloso, ibid., p. 10, y RidAura MarTínez, ibid., pp. 22-23. Esa concepción «trivializada» y metajurídica del orden público se exhibe de manera paradigmática en la STS de 5.4.1966, que lo define como aquellos «principios jurídicos públicos y privados, políticos, económicos, morales e incluso religiosos, necesarios para la conservación del orden social en un pueblo y en una época determinada». 
Como se dijo antes, la CE no define el orden público y apenas si lo nombra ${ }^{59}$. En su defecto, la jurisprudencia viene describiéndolo, según el caso, en su noción restringida (como situación de hecho, identificada con el «mantenimiento del orden en sentido material en lugares de tránsito público») ${ }^{60}$ o amplia («situación que permite el ejercicio pacífico de los derechos y libertades públicas y el correcto funcionamiento de las instituciones y organismos públicos, y consiguientemente, el cumplimiento libre y adecuado de las funciones públicas, en beneficio de intereses que superan los meramente individuales $»^{61}$ ). Esta última definición no deja claro si la alteración del orden público ha de verificarse exclusivamente a partir de criterios jurídicos, o se admiten también los metajurídicos. Algún autor traza precisamente aquí la frontera entre seguridad y orden públicos ${ }^{62}$, cifrando la utilidad de este en la «imposibilidad de la previsión ex ante por el ordenamiento jurídico [...] de todos los supuestos de posible perturbación de la convivencia ordenada» ${ }^{63}$.

Frente a esta postura, y a modo de conclusión a lo hasta ahora expuesto, debe afirmarse que el orden público «solo puede ser un orden positivo, esto es, un orden establecido por el Derecho y no por una difusa conciencia social que no tenga traducción en concretas normas jurídicas» ${ }^{64}$. Esta lectura nos conduce a una conclusión evidente: bajo la égida de la $\mathrm{CE}$, el orden público material solo puede identificarse con la seguridad ciudadana, es decir, con aquellas actividades nucleares de la seguridad pública «que se insertan en el conjunto de los cometidos ordinarios y normales de las Fuerzas y Cuerpos de Seguridad»: la protección de las personas y bienes frente a acciones violentas o agresiones,

59 Quizá lo más parecido a una definición del orden público en una norma estatal se encuentre en el tenor del art. 13 de la Ley Orgánica 4/1981, de 1 de junio, sobre estados de alarma, excepción y sitio, que prevé la declaración del estado de excepción «cuando el libre ejercicio de los derechos y libertades de los ciudadanos, el normal funcionamiento de las instituciones democráticas, el de los servicios públicos esenciales para la comunidad, o cualquier otro aspecto del orden público [...]». Se alude aquí, sin duda, a una concepción amplia de orden público.

60 Por todas, véanse las SSTC 164/2006, de 22.5, y 66/1995, de 8.5.

61 Por todas, véanse las SSTS 445/2016, de 25.5, y 1030/2007, de 4.12. Nótese la clara influencia sobre esta última definición del ya citado art. 3.4. ${ }^{\circ}$ de la Ley de Orden Público republicana.

62 Véase Parejo Alfonso, ibid., p. 77, para quien «[l]a seguridad ciudadana o pública [él las trata indistintamente] es la relativa a la efectividad del orden jurídico, es decir, al Estado como un todo y, por tanto, a sus instituciones y al funcionamiento de las mismas, así como a los derechos y bienes de los sujetos ordinarios o privados. El orden público alude más bien a los comportamientos que, aun no estando reglados, son considerados por la conciencia colectiva como presupuesto mínimo indispensable para la convivencia ordenada [...] los principios y valores incluso metajurídicos que están en la base de la convivencia social» (la cursiva es mía).

63 Parejo Alfonso, ibid., p. 77.

${ }^{64}$ Carro Fernández-Valmayor, ibid., p. 15. Al respecto, véase asimismo Álvarez GarCÍA, «La nueva reforma...», ibid., p. 29. 
situaciones de peligro o calamidades públicas ${ }^{65}$. Por su parte, el orden público formal o en sentido amplio posee - como se ha visto y se verá de nuevo enseguida - un contenido más amplio que la seguridad pública, la cual comprende, recuérdese, tanto de las actividades de seguridad ciudadana como las pertenecientes en puridad a otros ámbitos materiales que, en pos de proteger el libre ejercicio de los derechos y libertades (art. 104.1 CE), la seguridad pública reclama para sí en ejercicio de su vis atractiva.

\subsection{Bien jurídico protegido en el Capítulo II, Título XXII del Código Penal}

Hasta no hace demasiado, el bien jurídico protegido por los delitos de atentado, resistencia y desobediencia se identificaba con el principio de autoridad $^{66}$. Esta tesis descansaba en la pretendida trascendencia que para el cumplimiento de los fines del Estado tiene el respeto debido a sus órganos $^{67}$. Sin embargo, la jurisprudencia ${ }^{68}$ coincide hoy en que la condición de autoridad, agente o funcionario público no confiere por sí sola ninguna prerrogativa específica: la autoridad y su «protección» penal se derivan, en todo caso, del ejercicio legítimo de las funciones encomendadas ${ }^{69}$. En con-

65 En este sentido, véase CARro FERnÁndez-VALMAYOR, ibid., p. 14.

66 Se refieren a ello, por todos, VÁzQuez GonzÁlez, C., en SERrano GómEz, A. y otros: Curso de Derecho Penal. Parte Especial, 3. ${ }^{a}$ ed., Ed. Dykinson, Madrid, 2016, p. 833; SuÁrez-Mira Rodríguez, C., en SuÁrez-Mira Rodríguez, C. (coord.): Manual de Derecho Penal. Tomo II. Parte especial, Ed. Thomson Reuters, Cizur Menor, 2011, p. 646; ZÁRATE CondE, A. (coord.): Derecho Penal. Parte Especial, Ed. Universitaria Ramón Areces, Madrid, 2016, p. 959; y sobre todo Torres Fernández, M.E.: «Los delitos de atentado en el Código Penal de 1995", Revista Electrónica de Ciencia Penal y Criminología, 1.8 de 1999 (última consulta el 20.6.2018), así como la abundante bibliografía y jurisprudencia allí citadas.

67 Señalaba OCTAVIO DE TOLEDO y UBIETO que esta noción se remonta al concepto de maiestas o soberanía: en Roma se entendía que el atentado a la autoridad atacaba, junto a la potestas o poder de mando del funcionario público, su dignitas o decoro. Recogiendo esta visión, la codificación penal española del siglo XIX ubicó los delitos de atentado en el Capítulo dedicado a los delitos de lesa majestad ( $E l$ bien jurídico protegido en los Capítulos VI y VII del Título II del Código Penal», CPC, núm. 1, 1977, pp. 115-117 y 123).

68 Por todas, véase la STS 950/2000, de 4.6, cuyo tenor reza: «en una sociedad democrática, en la que rige una jerarquía de valores distinta a las de un régimen autoritario, no es adecuado identificar el bien jurídico protegido con el principio de autoridad, sino en la necesidad de que los agentes públicos, que actúan al servicio de los ciudadanos, gocen de la posibilidad de desempeñar sus funciones de garantía y protección sin interferencia ni obstáculos, siempre que actúen en el ejercicio legítimo de su cargo».

69 Por su parte, afirma CARRETERo SÁNCHEZ que «el bien jurídico protegido por el atentado sigue siendo el principio de autoridad democrática [...] El hecho de que cualquier persona que auxilie a los agentes de la autoridad pueda ser sujeto pasivo de atentado, refuerza la idea de que el principio de autoridad democrática es, sin duda, el interés protegido por este delito, ya que otorga a un ciudadano cualquiera el carácter de agente de la autoridad cuando acude en su auxilio» («El delito de atentado, resistencia y desobediencia a la autoridad y sus agentes tras la reforma del Código Penal», La Ley, 7745/2015, p. 2). 
secuencia, la dignidad por razón del cargo se convierte en una dignidad de la función pública, atributo necesario para el buen funcionamiento de los poderes públicos. Tal dignidad integraría el bien jurídico protegido por el atentado ${ }^{70}$. Sobre esta propuesta se volverá enseguida; baste apuntar ya que el concepto «dignidad de la función pública» sortea hábilmente el escollo en que caía la "dignidad inherente al cargo", individual por defecto: el bien jurídico tutelado por los delitos de atentado, resistencia, o desobediencia ha de ser colectivo, pues una pluralidad de sujetos pasivos atacados no da lugar a un número equivalente de delitos de atentado, sino a una única infracción ${ }^{71}$.

Puestos a encontrar un bien jurídico común a las conductas contenidas en los arts. 550 a $554 \mathrm{CP}^{72}$, no encajaría en esta matriz el orden público material ${ }^{73}$, que identificamos con la seguridad ciudadana. En efecto, si se mantiene la definición del orden público restringido o seguridad ciudadana como «mantenimiento del orden en sentido material en lugares de tránsito público» y se repara en que el art. $550 \mathrm{CP}$ prevé entre otros el atentado contra funcionarios docentes y sanitarios «en el ejercicio de sus funciones», es decir, en sus puestos de trabajo, habrá de concluirse que a estos delitos se les queda corta la seguridad ciudadana como bien jurídico tutelado.

En tiempos recientes, numerosas voces han identificado el bien jurídico tutelado en los arts. 550 a $554 \mathrm{CP}$ con el orden público en sentido amplio $^{74} \mathrm{o}$ más bien con formulaciones más específicas, reconducibles

70 Entiende Vives Antón (por todos, en Vives Antón, T.S. (coord.): Derecho Penal. Parte Especial, Ed. Tirant lo Blanch, Valencia, 2010, p. 765) que el bien jurídico protegido por el atentado sería «la dignidad de la función pública», esto es, la dignidad como requisito necesario para el buen funcionamiento de los poderes públicos.

${ }_{71}$ Sobre esta circunstancia, véanse por todos SUÁREz-MIRA RodRíGuez, ibid., p. 652, y VÁzouez GonZÁlez, ibid., p. 838.

${ }_{72}$ Restrinjo la búsqueda al delito de atentado porque en realidad el art. $556 \mathrm{CP}$ solo incluye a algunos de los sujetos pasivos contenidos en los delitos de atentado: el art. 556.1 $\mathrm{CP}$ a la autoridad, sus agentes y el personal de seguridad privada; y el $556.2 \mathrm{CP}$, a los agentes de la autoridad. De este modo, lo concluido para los más (atentado) debería valer asimismo para los menos (resistencia y desobediencia).

${ }^{73}$ Parece defender este criterio MuÑoz CONDE, que describe la «tranquilidad o paz en las manifestaciones colectivas de la vida ciudadana» como bien jurídico protegido por el delito de atentado. Véase Muñoz Conde, F.: Derecho Penal. Parte Especial, Ed. Tirant lo Blanch, Valencia, 2017, p. 741, así como Llobet Anglí, M., en Silva SÁnchez, J.M. (dir.): Lecciones de Derecho Penal. Parte Especial, Ed. Atelier, Barcelona, 2011, pp. 385-386. Por su parte, LAMARCA PÉREZ se inclina por una expresión muy similar: la consecución de un «clima material de tranquilidad en las manifestaciones colectivas de la vida social». Véase Lamarca Pérez, en Lamarca Pérez, C. (coord.): Delitos. La parte especial del Derecho penal, Ed. Colex, Madrid, 2015, p. 845.

${ }^{74}$ Expresamente, la Consulta 2/2008 de la Fiscalía General del Estado, p. 9: «se puede concluir que el bien jurídico protegido por el delito de atentado es el orden público en sentido amplio, en cuanto las conductas que le afectan están dirigidas a menoscabar la actuación de los sujetos expresados en la norma penal en el ejercicio regular de prestaciones relativas al interés general». 
a la garantía del buen funcionamiento de las funciones y servicios públicos ${ }^{75}$. En pos de tal garantía, «por el ataque a la función pública que encarna el sujeto pasivo y cuyo respeto es necesario para la convivencia en una sociedad democrática ${ }^{76}$, es que se ofrece una "protección» penal a quienes prestan y ejercen estos servicios y funciones como encarnación del Estado.

A nuestros ojos, el bien jurídico tutelado por el Capítulo II debe ser, en efecto, el buen desempeño de las funciones y servicios públicos ${ }^{77}$. En lo sustancial, esta opinión no se aleja de lo propuesto por VIVES ANTón, esto es, la «dignidad de la función pública» como requisito necesario para el buen funcionamiento de los poderes públicos; quizá la diferencia resida en que esta adelanta algo más la barrera de la «protección» penal, pues en la práctica serán no pocos los casos en que, aun no lesionándose ni poniéndose en peligro el buen desempeño una función o servicio público, sí puede haberse afectado a la dignidad de la función pública. Al margen de que la «dignidad» sea o no el parámetro más adecuado para informar un bien jurídico que, como el resto, debe construirse exclusivamente a partir de conceptos jurídicos, no procede extenderse más aquí sobre el particular.

El buen desempeño de las funciones o servicios públicos es, por un lado, un concepto más amplio que el mero orden público material: contiene a la seguridad ciudadana, pero no se agota en ella. Recuérdese que esta consistía en aquellos cometidos «ordinarios y normales» de las Fuerzas y Cuerpos de Seguridad, mientras que la seguridad pública abarcaba, llegado el caso, actuaciones en ciertos ámbitos en principio ajenos a ella pero que podían afectar al interés general (salubridad, catástrofes naturales, medio ambiente o protección civil). El concepto de buen desempeño de las funciones y servicios públicos integra todas esas contingencias: si se declara un incendio y se ordena a la Policía Nacional actuar en las tareas de extinción, quizá tal actividad no forme parte de sus cometidos «ordinarios y normales», pero sí caerá dentro de la seguridad pública; del mismo modo, el personal de protección civil quedaría comprendido por la misma, al igual que el personal de seguridad privada si el órgano competente ordena su

75 Por todos, véanse SuÁrez-Mira Rodríguez, ibid., pp. 643-647; Quintero OlivaRes, G., en Quintero Olivares, G. (dir.): Comentarios a la parte especial del Derecho Pe-

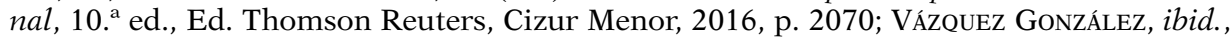
p. 829; ZÁrATE CONDE, ibid., p. 959, así como las SSTS 1030/2007, de 4.12, 361/2002, de $4.3,387 / 2000$, de 18.2 , y la ya citada 950/2000, de 4.6.

76 Consulta 2/2008 de la Fiscalía General del Estado, p. 15.

77 Se acepta la crítica de que los actos de desobediencia o de resistencia menos grave afectan al bien jurídico en menor medida, indirectamente si se quiere, que las conductas de atentado. Ocurrirá a veces que, en pos de una coherencia sistemática necesaria, el bien jurídico "general» propuesto no ayuda igualmente a la interpretación de cada uno de los delitos que lo protegen. 
participación. Otro ejemplo: un médico es agredido en el parking de un hospital público con ocasión de sus funciones allí realizadas, hecho que lesiona o pone en peligro el buen desempeño del servicio público de salud; sin embargo, si acto seguido interviene un agente de la Policía Nacional y también resulta agredido, dicha agresión no será ya típica en atención al buen desempeño del servicio público de salud, sino a la función pública de seguridad ${ }^{78}$. En ambos casos, la tipicidad de las agresiones se corresponde con la lesión o puesta en peligro del mismo bien jurídico "genérico» —o si se prefiere, con distintas facetas del mismo-.

Y por otro lado, el buen desempeño de funciones y servicios públicos es más restringido que el concepto de orden público formal. Definido este como "situación que permite el ejercicio pacífico de los derechos y libertades públicas y el correcto funcionamiento de las instituciones y organismos públicos, y consiguientemente, el cumplimiento libre y adecuado de las funciones públicas, en beneficio de intereses que superan los meramente individuales», se aprecia a primera vista que el atentado se centra en "proteger» solo un segmento de esta definición: las prestaciones de interés general. Lo cual tiene pleno sentido si se atiende a la propia razón de ser de estas funciones y servicios públicos: precisamente la de asegurar el ejercicio pacífico de ciertos derechos y libertades públicas. Las vulneraciones al ejercicio de cualquier derecho sufridas por un ciudadano a título individual merecen sin duda una respuesta, penal o no; pero lo tutelado en el Capítulo II, Título XXII responde a otra circunstancia: al daño potencial que causa a todos los ciudadanos el desempeño anormal de las funciones y servicios públicos ${ }^{79}$.

Un último apunte: frente a la posibilidad de que el bien jurídico tutelado en los arts. 550 a $556 \mathrm{CP}$ se identifique con el orden público en sentido amplio, señala críticamente MuÑz CONDE que este abarcaría casi todos los delitos tipificados en el Código, por lo que su contribución a efectos sistemáticos sería "casi nula» ${ }^{80}$. A ello cabe hacer dos apreciaciones.

78 Pues, como señala IzU Belloso, el presupuesto de la seguridad pública es siempre una situación de violencia (latente o consumada, de origen humano o natural): «[1] a protección de personas y bienes en que consiste la seguridad pública se realiza [...] ante agresiones violentas, o el peligro de que se produzcan éstas. Es precisamente esa nota de violencia la que justifica que un papel destacado en el mantenimiento de la seguridad pública recaiga sobre los Cuerpos de Policía, que son los órganos administrativos específicamente preparados para actuar por medio de la fuerza» (IzU BELLOSO, ibid., p. 15).

79 En este sentido, se muestra paradigmáticamente clara la ya citada STS 1030/2007, de 4.12: con el delito de atentado se sancionan «los hechos que atacan al normal funcionamiento de las prestaciones relativas al interés general que la Administración debe ofrecer a los ciudadanos».

${ }^{80}$ MuÑoz Conde, ibid., p. 741. 
La primera, crítica: si entendemos el bien jurídico protegido como el denominador teleológico común a todos los supuestos tipificados de un delito, y este prevé a su vez un catálogo en extremo abierto de sujetos pasivos, habrá que congraciarse por fuerza con cierta apertura del bien jurídico. En este sentido, su propuesta de «tranquilidad o paz en las manifestaciones colectivas de la vida ciudadana» ${ }^{81}$ parece varada entre dos orillas: por un lado, adolece de la misma amplitud que él critica (¿o no entran en tal bien jurídico la estafa, el hurto o el asesinato?), y por otro se queda corto al no integrar todos los supuestos de hecho del art. $550 \mathrm{CP}$, no digamos los del art. $554 \mathrm{CP}$ (piénsese solo en los casos del art. 554.3.a) CP: ¿es la «tranquilidad o paz en las manifestaciones colectivas de la vida ciudadana» el motivo por el que se tipifican las agresiones al personal de protección civil que actúa con ocasión de un incendio?).

Y la segunda, asertiva: en efecto, la cuestión no reside - como parece entender la Fiscalía General del Estado en su Consulta 2/2008 ${ }^{82}$ - en qué delitos afectan más o menos a "principios básicos de convivencia en una sociedad democrática», pues tales principios, básicos o no, solo interesan a nuestros efectos cuando además estén contenidos en normas jurídicas ${ }^{83}$. La cuestión reside en el distinto plano de dañosidad (como mínimo simbólica) en que se mueven las conductas tipificadas en los arts. 550 a 556 CP. A cualquiera se le hace evidente que la agresión, en el ejercicio de sus funciones o con ocasión de ellas, a quien contribuye a prestaciones relativas al interés general merece un mayor reproche que la perpetrada contra quien simplemente no se halla en tal posición. Que el legislador haya decidido canalizar este mayor desvalor a través de un delito independiente es cuestión aparte. Lo relevante a efectos del tema aquí tratado es que, si bien casi todos los delitos del Código protegen el orden público en sentido amplio, no todos tutelan el buen desempeño de las funciones y servicios públicos: esta es la función específica de los ubicados en el Capítulo II, Título XXII.

81 Véase MuÑoz Conde, ibid., p. 741.

82 Donde se señaló que las actividades realizadas por profesores de centros públicos en el marco del derecho a la educación «constituyen materias que afectan a los principios básicos de convivencia en una sociedad democrática, y por tanto, al bien jurídico protegido en el delito de atentado». Véase el citado documento, p. 19.

83 Sentencia de manera brillante MARTín-Retortillo Baquer, a propósito del ejercicio de derechos en presencia de cláusulas generales de orden público, que «en una resta cuanto más grande es el sustraendo, menor será el resultado». Me permito añadir que siquiera para empezar a restar hacen falta un minuendo (derechos y libertades) y un sustraendo (aquí, "principios básicos de convivencia en una sociedad democrática») que sean iguales, es decir: normas jurídicas. Si nos ponemos a restar churras y merinas no andaremos tan lejos de aceptar patentes de corso como la del «buen orden de la comunidad» ("gute Ordnung des Gemeinwesens»), cláusula que subordinaba la efectividad de los derechos a una serie de valores ético-sociales mayoritarios, paralelos a la estructura jurídico-normativa y, por supuesto, cambiantes con el tiempo y diferentes de un lugar a otro. 


\subsection{Especialidad del artículo 554.3.b) del Código Penal}

Llegados a este punto nos planteamos si tiene sentido, al elevarse la potencia del análisis al nivel «delito» - y por consiguiente reducirse el número de sujetos pasivos-, perfilar asimismo el bien jurídico protegido por el art. 554.3.b) CP.

La clave la proporciona la expresión «personal de seguridad privada, debidamente identificado, que desarrolle actividades de seguridad privada en cooperación y bajo el mando de las Fuerzas y Cuerpos de Seguridad». Como se ha visto, el personal de seguridad privada se encuentra legalmente habilitado para participar en una serie de actividades que, de acuerdo con lo hasta ahora expresado, caerían en el ámbito material de la seguridad ciudadana - como se vio, misión exclusiva de las Fuerzas y Cuerpos de Seguridad ex art. 104.1 CE. Al margen de este hecho, de enorme trascendencia en relación con otros debates, lo cierto es que el art. 554.3.b) CP condiciona la tipicidad del atentado a que la acción típica trascurra cuando el personal de seguridad privada «desarrolle actividades de seguridad privada», y además lo haga "en cooperación y bajo el mando de las Fuerzas y Cuerpos de Seguridad» (ambas condiciones integran el mismo elemento objetivo específico del tipo). Como vimos en otro epígrafe, la primera de estas condiciones remite al catálogo del art. 5.1 LSP, cuya rúbrica reza precisamente «Actividades de seguridad privada». En principio, todas las actividades allí enumeradas resultan subsumibles en la noción de seguridad ciudadana aquí manejada — actividad dirigida a la protección de las personas y bienes frente a acciones violentas o agresiones, situaciones de peligro o calamidades públicas. Con independencia de lo que se dirá más adelante sobre las cláusulas de los arts. 8.2 y 30.h) LSP, la conclusión que se alcanza es clara: todos los supuestos contemplados en el art. 5.1 LSP entran dentro de la concepción de seguridad ciudadana aquí defendida, por lo que puede concluirse que el bien jurídico protegido por el delito de atentado contra el personal de seguridad privada es el buen desempeño de la función pública de seguridad ciudadana.

\section{Tres ojeadas al artículo 554.3.b) del Código Penal}

Nos adentramos en el estudio de los elementos típicos objetivos del art. 554.3.b) CP. Consagrados a tal tarea, se erige necesario ante todo valorar hasta qué punto puede ayudar en esta exégesis los trabajos y jurisprudencia existentes sobre el delito de atentado "clásico». En otras palabras, nos interesa conocer qué tipo de relación existe entre ambos delitos para saber si podemos extrapolar ciertas conclusiones ya conocidas respecto del atentado "clásico». El estudio de esta relación entre los arts. 554.3.b) y $550.1 \mathrm{CP}$, así como la ponderación sobre la trascendencia de este hecho para el análisis ulterior, resulta más sencillo si dividimos el examen en tres pasos. 


\subsection{Primera ojeada. El artículo 554.3.b) en solitario}

En rigor, la primera lectura del art. 554.3.b) CP nos revela solo sus aspectos básicos. Se trata de un delito común, de mera actividad y estructura aparentemente sencilla: un tipo mixto alternativo con tres modalidades ("quienes acometan, empleen violencia o intimiden gravemente»), un sujeto pasivo cuyos exactos contornos se encarga de delimitar la legislación administrativa ("personal de seguridad privada») así como dos elementos objetivos adicionales que, a modo de condiciones cumulativas, restringen los supuestos en que la realización de alguna de las acciones típicas sobre el sujeto pasivo resulta típica: el que este se encuentre, al tiempo de perpetrarse la conducta típica: a) debidamente uniformado y b) desarrollando actividades de seguridad privada en cooperación y bajo el mando de las Fuerzas y Cuerpos de Seguridad.

Este primer vistazo al art. 554.3.b) también nos revela algo singular: con la reforma, la pena para esta nueva clase de atentado pasa a ser la misma que la del atentado «clásico» («se impondrán las penas de los artículos 550 y 551»). En realidad, este hecho no debe producir más que una fugaz sorpresa, pues nada trascendente se ha dicho aún sobre el delito y se sabe que ninguna pena —salvo quizá las prescritas por el artículo $15 \mathrm{CE}$ - puede valorarse al margen de su presupuesto de hecho. Valga solo apuntar aquí, a modo de comentario histórico, que la igualdad de trato penológico entre los profesionales de la seguridad privada y los miembros de los cuerpos de seguridad del Estado fue, desde el regreso de la democracia a España en 1977, una de las principales y más constantes demandas del sector privado de la seguridad. Hasta la LO 1/2015 los tribunales apenas consideraron al personal de seguridad privada como sujeto pasivo del atentado "clásico», y los supuestos que ahora subsumiríamos en el art. 554.3.b) CP se reconducían, en su caso, al tipo de atentado contra quien acude en auxilio de la autoridad, sus agentes o funcionarios (antiguo art. $555 \mathrm{CP})^{84}$, un régimen ciertamente menos protector con el sujeto pasivo que el del atentado "clásico» ${ }^{85}$. Esta diferencia de trato fue gestando un creciente malestar en el sector de la seguridad privada, que veía década tras década cómo se ampliaban sus atribuciones y responsabilidades pero no su «protección» penal.

${ }^{84}$ Cuyo tenor disponía: «Las penas previstas en los artículos 551 y 552 se impondrán en un grado inferior, en sus respectivos casos, a los que acometan o intimiden a las personas que acudan en auxilio de la autoridad, sus agentes o funcionarios».

${ }_{85}$ El antiguo art. 555 CP solo incluía dos - acometimiento e intimidación- de las conductas típicas previstas en el atentado «clásico» previo a la reforma -acometimiento, empleo de fuerza, intimidación grave y resistencia activa grave-, así como un marco penológico inferior: la pena inferior en uno o dos grados respecto a las del antiguo art. $551 \mathrm{CP}$. 


\subsection{Segunda ojeada. El artículo 554.3.b) dentro del artículo 554}

Un segundo vistazo al art. 554.3.b) CP, esta vez en conexión con el resto de apartados del art. 554, arroja dos nuevas ideas. En sus tres breves apartados, el art. 554 contiene hasta cuatro supuestos «nucleares» de atentado, cada uno singularizado por la especie de sujeto pasivo a la que se circunscribe; cuatro colectivos a los que el legislador, en razón de su particular relación con el bien jurídico protegido, desea ofrecer bajo ciertas condiciones una "protección» penal reforzada: los miembros de las Fuerzas Armadas (554.1), las personas que acuden en auxilio de sujetos pasivos del atentado «clásico» (554.2), los bomberos o miembros del personal sanitario o equipos de socorro (554.3.a) y el personal de seguridad privada (554.3.b).

Todos estos supuestos tienen algo en común: la pena prevista para ellos resulta idéntica a la del atentado "clásico». Se aprecian, en lo demás, dos notables diferencias. La primera, respecto de las modalidades comisivas: mientras que el apartado 1 se remite directamente al catálogo de conductas típicas del atentado "clásico» ("Los hechos descritos en los artículos 550 y 551 »), los apartados 2 y 3 , por contra, enumeran cada uno su catálogo autónomo de conductas típicas ${ }^{86}$. Y la segunda diferencia: cada supuesto de atentado del art. $554 \mathrm{CP}$ alberga sus propios elementos objetivos específicos del tipo.

En realidad, de la primera diferencia poco puede decirse hasta que no cotejemos las modalidades comisivas del art. $550.1 \mathrm{CP}$, tarea que corresponde al siguiente punto. Sí pueden subrayarse ahora dos datos. El primero, que los dos supuestos de atentado "atípico» ya previstos antes de la reforma - los antiguos arts. 554 y 555, ahora apartados 1 y 2 del art. 554, respectivamente- aumentan su elenco de conductas típicas: el atentado contra "fuerza armada», que antes contemplaba una sola modalidad (la resistencia activa grave), pasa a remitirse (art. 554.1) a las tres modalidades del atentado "clásico»; y el antiguo art. 555, que solo admitía el acometimiento y la intimidación, incluye ahora el empleo de fuerza (art. 554.2). Segundo dato: los catálogos autónomos de conductas típicas de los apartados 2 y 3 del art. 554 CP son prácticamente idénticos: solo difieren en que el inciso del apartado 3 puntualiza, siguiendo la línea legislativa tradicional desde 1870, que la intimidación típica del atentado debe ser "grave» ${ }^{87}$. Realmente no se explica la ausencia de tal referencia en el art. 554.2 CP.

La segunda diferencia -los elementos objetivos específicos de cada tipo- tampoco puede estudiarse en profundidad de momento. Como se apuntó arriba, tres de los cuatro supuestos de atentado «atípico»—la

\footnotetext{
${ }^{86}$ Aunque en puridad el catálogo no es el mismo, como se verá enseguida.

87 Véase al respecto la Consulta 1/2017 de la Fiscalía General del Estado, pp. 10-11.
} 
excepción es el art. 554.2 - contienen una serie de elementos objetivos específicos que, a modo de condiciones adicionales, perfilan la tipicidad de cada supuesto ${ }^{88}$. La naturaleza exacta de estos elementos, de nuevo, solo se revelará tras el careo con el art. 550.1 CP.

Sí cabe aquí un apunte histórico. Hasta la reforma, el supuesto de atentado contra «fuerza armada» (antiguo art. $554 \mathrm{CP}$ ) contenía tres elementos objetivo específicos del tipo: a) que la conducta típica contra el sujeto pasivo se verificara durante el ejercicio de sus funciones o con ocasión de ellas (antiguo art. 554.1); b) más concretamente, que la conducta típica se produjese durante o con ocasión de la prestación de un servicio legalmente encomendado a las Fuerzas Armadas y reglamentariamente ordenado al propio sujeto pasivo (art. 554.2), y c) que el sujeto pasivo, en cualquier caso, vistiera uniforme al tiempo de la acción típica (antiguo art. 554.2). Tras la reforma, el primero de los elemento desaparece y del segundo se elimina la debida conexión entre el atentado y la prestación de un servicio reglamentariamente ordenado. Permanecen por lo tanto el tercer elemento y lo restante del segundo, es decir, el sintagma «vistiendo uniforme, estuviera prestando un servicio que le hubiera sido legalmente encomendado».

\subsection{Tercera ojeada. Los artículos 554.3.b) y 550.1}

Con el tercer vistazo al tenor literal del art. 554.3.b) CP, esta vez en conexión con el art. 550.1, damos en el busilis. La pregunta a resolver es: ¿qué relación guardan ambos delitos? ¿Se trata de una relación de especialidad, o de autonomía? En el primer caso:

a) los elementos comunes al tipo básico (art. 550.1) y al nuevo tipo especial (art. 554.3.b) se interpretarían conforme al contenido ya existente del tipo básico (función arquetípica del tipo básico), y

b) el tipo especial se integraría, además de por sus elementos típicos específicos, por los del supuesto básico allí donde no resulte incompatible con aquellos o donde el art. 554.3.b) no se pronuncie.

En el segundo caso, el tipo básico no complementaría en nada el contenido del autónomo, que se valdría por sí solo, lo cual permitiría dotar de contenido propio incluso a los elementos del art. 554.3.b) compartidos con el tipo básico de atentado.

88 Así, el art. 554.1 CP contiene dos elementos objetivos específicos: que al tiempo de verificarse la conducta típica el sujeto pasivo se hallara a) vistiendo uniforme, y b) prestando un servicio que le hubiera sido legalmente encomendado. Por su parte, el art. 554.3.a) prevé un solo elemento: que al tiempo de verificarse la conducta típica el sujeto pasivo se encontrase interviniendo con ocasión de un siniestro, calamidad pública o situación de emergencia. Y en cuanto a los elementos objetivos específicos del art. 554.3.b) CP, fueron enumerados arriba. 
Sujetos pasivos y elementos objetivos específicos son las dos categorías que cualifican al art. 554.3.b) respecto del 550.1. Consagramos las siguientes líneas a su estudio, del que extraeremos ideas útiles para el ulterior examen de las modalidades comisivas del $554.3 \mathrm{~b}$ ).

A) Respecto del sujeto pasivo, el delito de atentado "clásico» se circunscribe a tres grupos: las autoridades, los agentes de la autoridad y los funcionarios públicos a efectos penales. Por su parte, el delito del art. 554.3.b) solo contempla uno: el personal de seguridad privada.

¿Podemos derivar de aquí una relación de especialidad? Así ocurriría si el personal de seguridad privada fuera una categoría subsumible en uno de los tres arquetipos del art. 550.1, razón por la que el legislador, voluntarioso por darle a aquel colectivo un trato personalizado, habría introducido un precepto especial que, en lo no regulado por este, seguiría recibiendo los elementos objetivos específicos del supuesto básico. Si por el contrario se trata de una relación de autonomía, el legislador habría introducido, a la vista de que el personal de seguridad privada no encajaba holgadamente en ninguna de las categorías de sujeto pasivo previstas en el Capítulo II, Título XXII, un delito autónomo para reforzar la "protección» penal de este colectivo.

Precisamente en tal rincón del Código encontramos dos ejemplos de atentado especial respecto del atentado «clásico». Uno es el regulado en el art. 554.1 CP, pues los miembros de las Fuerzas Armadas son siempre funcionarios, y a veces autoridades o agentes de la misma. Y el otro, el del art. 554.3.a) CP, ya que tanto bomberos como miembros del personal sanitario o equipos de socorro pueden ser funcionarios públicos a efectos penales ${ }^{89}$. Piénsese que, de no existir un art. 554, el atentado contra estos grupos de sujetos se regiría directamente por el precepto del atentado «clásico». En este sentido, los artículos 554.1 y 554.3.a) actúan como tamiz donde quedan atrapados, excluidos del art. 550.1, los supuestos de atentado cometidos contra tales sujetos pasivos.

El caso del personal de seguridad privada requiere más larga glosa, si bien tenemos mucho avanzado. Como se vio, el concepto normativo "personal de seguridad privada» lo integran en principio "los vigilantes de seguridad y su especialidad de vigilantes de explosivos, los escoltas privados, los guardas rurales y sus especialidades de guardas de caza y guardapescas marítimos, los jefes de seguridad, los directores de seguridad y los detectives privados»(art. 26.1 LSP). Esta definición

89 Pues al definirse los sujetos pasivos del art. 554.3.a) CP precisamente en atención a la función realizada («que estuvieran interviniendo con ocasión de un siniestro, calamidad pública o situación de emergencia»), parece razonable abrirles la categoría tanto a los de naturaleza pública como privada, y aun a los que no mantengan relación funcionarial o contractual: los voluntarios. 
incluye a todos los sujetos que desempeñan funciones de seguridad privada $^{90}$, si bien tal conclusión queda matizada a la luz del bien jurídico tutelado por el art. 554.3.b), esto es, el buen desempeño de la función pública de seguridad ciudadana ${ }^{91}$. Así, solo puede considerarse sujeto pasivo de este delito a aquellos miembros del «personal de seguridad privada» que participen en la protección del bien jurídico tutelado en el art. 554.3.b) CP. Recuérdese que la seguridad ciudadana ha sido definida como la actividad dirigida a la protección de las personas y bienes frente a acciones violentas o agresiones, situaciones de peligro o calamidades públicas.

¿Qué colectivos profesionales del "personal de seguridad privada» participan en la protección de la seguridad ciudadana? Como también se vio, la LSP define a cada colectivo por las actividades de seguridad privada para las que está habilitado, lo cual podría ahora sernos de ayuda; sin embargo, todas las actividades del art. 5.1 LSP parecen encajar con la noción aquí defendida de seguridad ciudadana. Por otro lado, el examen de los elementos objetivos específicos del art. 554.3.b) CP nos sugiere que el inciso «en cooperación y bajo el mando de las Fuerzas y Cuerpos de Seguridad» puede servirnos para acotar el ámbito de aplicación del delito. Y así, echando mano de nuevo a la LSP comprobamos que el legislador solo alude a las Fuerzas y Cuerpos de Seguridad de manera significativa, a nuestros efectos ${ }^{92}$, al regular los servicios de vigilancia y protección (apartados 2 y 3 del art. 41 LSP) ${ }^{93}$, siempre atribuidos a los vigilantes de seguridad o en su caso guardas rurales ${ }^{94}$. Por lo tanto, a

90 Pues, conforme al tenor literal del citado art. 26.1 LSP, «únicamente» estos «pueden ejercer funciones de seguridad privada». Apuntala esta conclusión el tenor del art. 6.3 LSP al disponer que «[e]l personal no habilitado que preste los servicios o funciones comprendidos en el apartado anterior [actividades compatibles], en ningún caso podrá ejercer función alguna de las reservadas al personal de seguridad privada [...]».

91 En cuanto a la incidencia del bien jurídico sobre la determinación de los sujetos pasivos del atentado, véase la Consulta 2/2008 de la Fiscalía General del Estado, pp. 6-9.

${ }_{92}$ Pues en realidad también se alude a las Fuerzas y Cuerpos de Seguridad al regular los servicios de videovigilancia (apartado 4 del art. 42 LSP), si bien ahí solo se refiere a la obligación de facilitar a las Fuerzas y Cuerpos de Seguridad ciertas grabaciones, concretamente aquellas «relacionadas con hechos delictivos o que afecten a la seguridad ciudadana».

${ }_{93} \mathrm{El}$ art. 41 LSP sí contempla la posibilidad de una verdadera actuación conjunta de las Fuerzas y Cuerpos de Seguridad con el personal de seguridad privada: ciertas actividades solo podrán prestarse cuando se actúe «en coordinación, cuando proceda» (art. 41.2 LSP), «en coordinación, en todo caso» (art. 41.2.c) LSP) o "cumpliendo estrictamente las órdenes e instrucciones» (art. 41.3 LSP) de las Fuerzas y Cuerpos de Seguridad

${ }_{94}$ Así se desprende del tenor literal de ambos preceptos (art. 41.1: "Los servicios de vigilancia y protección referido a las actividades contempladas en el artículo 5.1.a) se prestarán por vigilantes de seguridad o, en su caso, por guardas rurales», y 42.1 in fine: "Cuando la finalidad de estos servicios sea prevenir infracciones y evitar daños a las personas o bienes objeto de protección o impedir accesos no autorizados, serán prestados necesariamente por vigilantes de seguridad o, en su caso, por guardas rurales»). 
efectos del art. 554.3.b) CP podemos concluir que la expresión «personal de seguridad privada» queda por lo general ${ }^{95}$ circunscrita a los vigilantes de seguridad y a los guardas rurales. Esta conclusión, por cierto, posee incidencia directa sobre la exégesis del elemento objetivo específico del art. 554.3.b) CP «desarrollar actividades de seguridad privada en cooperación y bajo el mando de las Fuerzas y Cuerpos de Seguridad»: en adelante entenderemos por «actividades de seguridad privada», al menos a efectos penales, las del art. 41 LSP.

Por supuesto, solo integran el colectivo "personal de seguridad privada» aquellos debidamente habilitados para desempeñar tales funciones $^{96}$ - lo cual excluye tanto el acceso irregular a la profesión como la pérdida sobrevenida de los requisitos ${ }^{97}$ - y solo en relación con las funciones concretas a las que esa habilitación se extiende ${ }^{98}$. De este

${ }_{95}$ Aunque la gran mayoría de supuestos imaginables de cooperación entre las Fuerzas y Cuerpos de Seguridad y el personal de seguridad privada quedará cubierta por este razonamiento, debe introducirse aquí un matiz. En efecto, el art. 8.2 LSP establece que "[l] os prestadores de servicios de seguridad privada colaborarán, en todo momento y lugar, con las Fuerzas y Cuerpos de Seguridad, con sujeción a lo que éstas puedan disponer en relación con la ejecución material de sus actividades» (la cursiva es mía); naturalmente, se refiere a las actividades de seguridad privada. Por lo tanto, las Fuerzas y Cuerpos de Seguridad pueden, llegado el caso, injerirse en cualquiera de las actividades del art. 5.1 LSP y adoptar disposiciones obligatorias para los «prestadores de servicios de seguridad privada». En el mismo sentido, el art. 30.h) LSP enuncia el principio básico de «colaboración con las Fuerzas y Cuerpos de Seguridad», por el cual el personal de seguridad privada debe, entre otras cosas, "seguir sus instrucciones en relación con el servicio de seguridad privada que estuvieren prestando». En conclusión, la posibilidad de una actuación conjunta de ambos colectivos puede llegar a extenderse a cualesquiera de las actividades del art. 5.1 LSP.

${ }_{96}$ Como bien se desprende del art. 52.3 RSP: «Para el desarrollo de sus respectivas funciones, el personal de seguridad privada habrá de obtener previamente la correspondiente habilitación o reconocimiento». Para obtener dicha habilitación, que tiene carácter de autorización previa y es expedida por el Ministerio del Interior, el personal de seguridad privada ha de reunir una serie de requisitos generales (arts. 28.1 LSP y 53 RSP) y específicos en atención a las funciones desempeñadas (art. 28.2 LSP y, para los vigilantes de seguridad, art. 54.2 RSP), así como solicitar su participación en las pruebas oficiales (arts. 58 RSP y 10 de la orden ministerial). Los nacionales de Estados Miembros de la Unión Europea o de Estados parte en el Acuerdo sobre el Espacio Económico Europeo tienen su propio régimen de habilitación (art. 55 bis RSP).

97 En este sentido véanse los arts. 10.1.c) LSP y 64.1.b) RSP). La constatación del incumplimiento de los requisitos necesarios produce la extinción automática de la habilitación y la cancelación de oficio de la inscripción en el Registro Nacional (art. 28.3 LSP). En estos casos, el RSP establece en su art. 65.1 la obligación del personal de seguridad privada de entregar, en el plazo de diez días, su tarjeta de identidad profesional al jefe de seguridad o al jefe de personal de la empresa en la que presten servicios, los cuales, a su vez, la entregarán en las dependencias de la Dirección General de Policía o de la Guardia Civil. En idéntico sentido, el art. 13.4 de la orden ministerial.

98 Como literalmente exponen los arts. 10.1.b) («Con carácter general y además de otras prohibiciones contenidas en esta ley, se establecen las siguientes: [...] El ejercicio de funciones de seguridad privada por parte de personas físicas carentes de la correspondiente habilitación o acreditación profesional») y 27.4 LSP: «El personal de seguri- 
modo, si al tiempo de perpetrarse los hechos el vigilante de seguridad no reúne los requisitos legal o reglamentariamente establecidos para las funciones que se hallaba desempeñando, tales hechos no podrán considerarse constitutivos de atentado "al personal de seguridad privada» en el sentido del art. 554.3.b) CP. Ello sin perjuicio de la aptitud, en su caso, para ser sujeto pasivo en el delito de atentado contra las personas que acuden en auxilio de la autoridad, sus agentes o funcionarios (art. 554.2 $\mathrm{CP}^{99}$ ).

Llevados estos antecedentes a la pregunta de salida, cabe plantearse entonces si los vigilantes de seguridad o guardas rurales resultan subsumibles en alguna categoría de sujetos pasivos del art. 550.1 CP. Evidentemente, no en la de autoridades; precisando cierta argumentación, tampoco a mi juicio en la de agentes de la autoridad o funcionarios públicos.

En relación con el carácter de agente de la autoridad, no fue infrecuente durante nuestra primera década democrática que cierta jurisprudencia, con base en algunas disposiciones reglamentarias, les otorgara tal condición ${ }^{100}$. Sin embargo, la STS de 25 de octubre de 1991 dio en cambiar esa situación al cristalizar la que después se daría en llamar «doctrina negativa de la condición de agentes de la autoridad». Tal doctrina vedó la condición de agentes de la autoridad a los vigilantes de seguridad en tanto que: a) no realizaban funciones públicas iure proprio, sino en todo caso complementarias o auxiliares a aquellas, y b) no existía norma de rango legal que les atribuyera tal condición. La doctrina se plasmó en la Ley 23/1992 —que omitió deliberadamente de su articulado la protección penal del personal de seguridad privada ${ }^{101}$, haciendo evidente que la actividad reglamentaria de la Administración no había de suplir tal silencio ${ }^{102}$-, y fue acogida,

dad privada ejercerá exclusivamente las funciones para los (sic) que se encuentre habilitado».

99 Para lo cual es preciso, por cierto, que la autoridad, sus agentes o los funcionarios públicos hubiesen reclamado o aceptado, expresa o tácitamente, el auxilio. En este sentido, véase CEREzo MiR. J.: «Los delitos de atentado propio, resistencia y desobediencia», en Cerezo Mir, J.: Problemas fundamentales del Derecho Penal, Ed. Tecnos, Madrid, 1982, p. 210.

100 Por todas, véanse las SSTS de 10.12 de 1983, de 8.11 de 1984 y de 18.12 de 1990 , referidas al Real Decreto 629/1978, de 10 de marzo, por el que se regulan diversos aspectos de la profesión de Vigilante jurado de seguridad. El art. 18 de esta norma afirmaba expresamente que a los vigilantes jurados de seguridad en el ejercicio de su cargo tendrían el carácter de agentes de la autoridad, siempre que prestasen el servicio de uniforme.

${ }^{101}$ Lo cual, por cierto, no los desprotegía penalmente en tanto que gozaban de protección frente a los que «acometieren» (art. 236 del CP 1973) o "acometan o intimiden» (art. 555 del CP 1995) a las personas que acudieren en auxilio de la Autoridad, sus agentes o funcionarios.

102 Por todos, véase Lorente Velasco, ibid., p. 105, así como las SSTS de 25.10 de 1991, de 6.5 de 1992 y de 18.11 de 1992. 
con escasos matices ${ }^{103}$, por la doctrina mayoritaria ${ }^{104} \mathrm{y}$ jurisprudencia unánime ${ }^{105} 106$.

Ciertamente, la actual LSP sí habilita a los vigilantes de seguridad a ejercer con autonomía toda una serie de actividades relacionadas con la seguridad ciudadana ${ }^{107}$, de lo cual se deduce que el requisito de realizar funciones públicas iure proprio puede entenderse cumplido. Lo que no hay por el momento es norma estatal ${ }^{108}$ de rango legal que les atribuya la condición de agentes de la autoridad. En ningún caso otorga este carácter el por lo demás discutible art. 31 LSP, que tan siquiera afir-

103 Algunos autores reclaman adicionalmente el requisito de que la norma otorgante de la condición de agente de la autoridad, por afectar a la definición de un tipo penal y en consecuencia a la imposición de una pena, debe revestir en todo caso carácter de ley orgánica. En este sentido, véanse Quintero Olivares, Comentarios a la parte especial..., ibid., 2016, p. 301; ÁlVAREZ GARCÍA/CARRASCo ANDRINo, "Los nuevos sujetos...», ibid., pp. 16-17 del original, así como las SSAP-Barcelona, Sección 9. a , 815/2016, de 26.10, Sección 3. , 151/2016, de 23.3, y Sección 10. ${ }^{\mathrm{a}}, 838 / 2015$, de 23.10.

104 Por todos, véanse Queralt Jiménez, J.J.: Derecho Penal Español. Parte Especial, 5. ${ }^{\mathrm{a}}$ ed., Ed. Atelier, Barcelona, 2008, p. 770; Cuerda ARnAu, M.L.: Los delitos de atentado y resistencia, Ed. Tirant lo Blanch, Valencia, 2003, pp. 56-57; CоBо DEL Rosal (coord.): Derecho Penal. Parte Especial, Ed. Dykinson, Madrid, 2005, p. 109, y LoRente Velasco, ibid., pp. 110-111.

105 Según LoREnTe Velasco, «en nuestros días [2010], resulta imposible encontrar un pronunciamiento judicial en el que profesionales de Seguridad Privada sean considerados agentes de la autoridad». Véase LoRENTE Velasco, ibid., p. 112.

106 Por su parte, la Consulta 3/1993 de la Fiscalía General del Estado consideró que los vigilantes en el ejercicio de las funciones de auxilio y colaboración con las Fuerzas y Cuerpos de Seguridad, «en tanto que colaboren o participen en el ejercicio de determinadas funciones públicas están protegidos penalmente como los agentes de la autoridad y funcionarios públicos» (la cursiva es mía). Realmente no se entiende qué puede significar ese «como»: si se refiere a que los vigilantes de seguridad, en tanto que sujetos pasivos del delito de atentado del entonces art. 236, párrafo segundo, del CP de 1973 - hoy art. 554.2 $\mathrm{CP}$ - están protegidos penalmente al igual que los agentes de la autoridad y funcionarios públicos (si bien con un régimen distinto), nada aportaba esta conclusión, y si se refiere a que están protegidos en los mismos términos que los agentes de la autoridad y funcionarios públicos se trata simplemente de un disparate: el tipo de atentado contra el auxiliador incluye dos modalidades comisivas menos, no protege frente a los atentados cometidos «con ocasión de» las funciones desempeñadas y prevé como marco penológico las penas inferiores en grado a las del atentado "clásico».

107 Primero, porque pueden prestar por sí solos servicios de vigilancia (previa autorización del órgano competente) en "complejos y parques comerciales y de ocio que se encuentren delimitados» (art. 41.2.b) LSP), así como en "acontecimientos culturales, deportivos o cualquier otro evento de relevancia social que se desarrolle en vías o espacios públicos o de uso común, en coordinación, en todo caso, con las Fuerzas y Cuerpos de Seguridad» (art. 41.2.d) LSP). Y segundo, porque pueden participar «[c] uando así se decida por el órgano competente, y cumpliendo estrictamente las órdenes e instrucciones de las Fuerzas y Cuerpos de Seguridad [...] en la prestación de servicios encomendados a la seguridad pública» (art. 41.3.d) LSP). Estos servicios de seguridad, y muy especialmente los del art. 41.2 LSP, no pueden entenderse ya como un mero complemento o auxilio a la función pública de seguridad, sino como verdadera participación iure proprio en ella.

108 Sobre esto, véase la reciente STC 50/2018, de 10.5. 
maba el carácter de agente de la autoridad del personal de seguridad privada ${ }^{109}$ sino que remendó una especie de tipo "frankenstein» con modalidades comisivas del futuro art. 550.1 (i!) y del 556 CP (agresión y desobediencia, respectivamente), el sujeto pasivo y los elementos objetivos específicos del futuro art. 554.3.b) y una consecuencia jurídica cuanto menos peliaguda a la vista del rango legal de la LSP ${ }^{110}$ : «[s]e considerarán agresiones y desobediencias a agentes de la autoridad» ${ }^{111}$. Con la inclusión del art. 554.3.b) en el Código, el art. 31 LSP deviene difícilmente aplicable.

Por su parte, respecto de la condición de funcionario público a efectos penales del personal de seguridad privada el art. 24.2 CP exige dos requisitos: a) un título válido de participación en el ejercicio de la función pública (disposición de la ley, elección o nombramiento) ${ }^{112}$, y

109 Cosa que tampoco puede, dado que el art. 7.1 de la LOFCS dispone que son exclusivamente los miembros de las Fuerzas y Cuerpos de Seguridad quienes ostentan el carácter de agentes de la autoridad. La LSP no posee rango legal para alterar ese contenido. Por supuesto, tampoco resultarían extrapolables al personal de seguridad privada las prerrogativas que asisten a los agentes de la autoridad en el seno del procedimiento administrativo o el proceso penal. Piénsese, sin ir más lejos, en las excepciones al principio de presunción de inocencia (art. 53 de la Ley 39/2015, de 1 de octubre, del Procedimiento Administrativo Común) en relación con ciertos actos de comprobación e inspección que, llevados a cabo por agentes de la autoridad, pueden sentar una presunción de veracidad (art. 77.5 de la Ley 39/2015, art. 89 del Real Decreto Legislativo 6/2015, de 30 de octubre, por el que se aprueba el texto refundido de la Ley sobre Tráfico, Circulación de Vehículos a Motor y Seguridad Vial, o el art. 52 LOPSC).

${ }_{110}$ Pues la LSP no tiene rango de ley orgánica, único válido para modificar la definición de un tipo penal y en consecuencia la imposición de una pena en tanto que afecta a derechos fundamentales. Entienden que existe reserva de ley orgánica en materia penal en tanto que su contenido sea relativo «al desarrollo de los derechos fundamentales y de las libertades públicas» (art. 81.1 CE), por todos, ARRoyo ZAPATERo, L.: «Principio de legalidad y reserva de ley en materia penal», Revista Española de Derecho Constitucional, núm. 8, 1983, pp. 24-27, y Quintero Olivares, en Quintero Olivares, G. (dir.): Comentarios al Nuevo Código Penal, 3. ${ }^{\text {a }}$ ed., Ed. Aranzadi, Cizur Menor, 2004, p. 301. En contra, véase LORENTE Velasco, ibid., p. 101, para quien también ostentan ese carácter, pese a que su otorgamiento no proceda de una ley orgánica, las personas que realizan labores de inspección de las actividades de gestión de recursos (art. 29.2 de la Ley 10/1998, de 21 de abril, de Residuos) o los agentes judiciales (art. 15.1 del Real Decreto 249/1996, de 16 de febrero, por el que se aprueba el Reglamento Orgánico de los Cuerpos de Oficiales, Auxiliares y Agentes al Servicio de la Administración de Justicia), entre otros.

111 Realmente no se entiende cómo el mismo legislador que aprobó un año después la LO 1/2015 pudo dar por buena esta redacción del art. 31 LSP: si consiguió anticipar el inciso «debidamente identificado, que desarrolle actividades de seguridad privada en cooperación y bajo el mando de las Fuerzas y Cuerpos de Seguridad» del futuro art. 554.3.b) CP, ¿por qué no hizo lo mismo con sus modalidades comisivas?

112 Véanse por todos Rebollo Vargas, R.: «Los conceptos penales de funcionario público y autoridad», en Córdoba Roda, J. / GARCia Arán, M. (dir.): Comentarios al Código Penal. Parte general, Ed. Marcial Pons, Madrid, 2011, pp. 318-320; así como las SSTS 83/2017, de $14.2,149 / 2015$, de 11.3 , la ya citada $166 / 2014$, de 28.2 , y la de 17.1 de 2003 , que consideró funcionario público a una persona nombrada por autoridad competente en un contrato laboral. Por su parte, señala Del Toro Marzal (citado por Rebollo VARgas, ibid., p. 319) que los tres títulos de participación pueden reducirse a uno, ya que la elección y el nombra- 
b) una participación efectiva en el ejercicio de dicha función pública ${ }^{113}$, con independencia de que el sujeto se incorpore formalmente a la Administración o de la temporalidad o permanencia en el cargo ${ }^{114}$. A efectos del segundo requisito, "participar en el ejercicio de funciones públicas» debe entenderse como ejercicio de la función y, por consiguiente, «capacidad del funcionario público para lesionar el bien jurídico en cada tipo concreto» ${ }^{115}$. En este sentido, puede afirmarse que el personal de seguridad privada participa en el ejercicio de una función pública en los términos requeridos por el Código. Sin embargo, no se verifica ningún título válido de participación en tal ejercicio, que aquí ${ }^{116}$ constituye un verdadero criterio de deslinde entre el funcionario a efectos penales y el mero particular que participa en el ejercicio de funciones públicas ${ }^{117}$. En efecto, la habilitación por «disposición inmediata de la ley» se encuentra vedada al personal de seguridad privada por cuanto esta se entiende circunscrita al nombramiento de los funcionarios de carrera ${ }^{118}$. En igual

miento deben por fuerza basarse en una disposición legal que legitime el procedimiento, de manera que la «disposición inmediata de la ley» no sería un título independiente sino la legitimación de los otros dos. Véase Del Toro Marzal, A., en Córdoba Roda, J. y otros: Comentarios al Código Penal, Tomo II, Ed. Ariel, Barcelona, 1972, pp. 735 y ss.

113 Por todos véanse Rebollo Vargas, ibid., pp. 320-322; Queralt JimÉnez, J.J.: «El concepto penal de funcionario público», CPC, núm. 27, 1985, pp. 484-488; RAMÓN RIBAS, ibid., pp. 178-182, así como las SSTS $166 / 2014$, de 28.2, 1590/2003, de 22.4, o la de 27.1.2993. La participación en el ejercicio de funciones públicas se extiende a las funciones del Estado, las Comunidades Autónomas o las Entidades Locales, e incluso de la llamada administración institucional, es decir «cuando una entidad pública adopta una forma independiente, incluso con personalidad jurídica propia, a veces hasta la de una sociedad mercantil, con el fin de conseguir un más ágil y eficaz funcionamiento. Cualquier actuación de estas entidades donde exista un interés público responde a este concepto amplio de función pública» (STS de 27.1.2003).

114 Por todos, véanse Lorente Velasco, ibid., p. 75, la Consulta 2/2008 de la Fiscalía General del Estado, p. 10, y las SSTS 1344/2004, de 23.12, 1290/2000, de 10.7, así como la ya citada de 27.1 de 2003 .

115 Rebollo Vargas, ibid., pp. 320-321.

116 Por contraposición a otros casos en los que el propio Código parece no dar importancia al título habilitante (v.g., el art. $423 \mathrm{CP}$, aplicable a «[...] cualesquiera personas que participen en el ejercicio de funciones públicas», o el art. $435.1{ }^{\circ} \mathrm{CP}$, aplicable «[a] los que se hallen encargados por cualquier concepto de fondos, rentas o efectos de las Administraciones públicas»; la cursiva es mía). Al respecto, véase RAMÓN RIBAS, ibid., pp. 189-191.

117 Señala Queralt Jiménez que, de no mediar en el art. 24.2 CP la exigencia de un título habilitante, ostentaría la condición de funcionario público incluso quien actúa en legítima defensa, pues tanto defiende el «legítimo defensor» la propia integridad como el ordenamiento jurídico. Véase QueRALt JiMÉNEZ, «El concepto penal de...», ibid., pp. 485-486.

118 En este sentido, véase Valeije Álvarez, I.: «Reflexiones sobre los conceptos penales de funcionario público, función pública y personas que desempeñan una función pública», CPC, núm. 62, 1997, pp. 453-456, la cual parte del tenor del art. 9.1 de la Ley 7/2007, de 12 de abril, del Estatuto Básico del Empleado Público ( Son funcionarios de carrera quienes, en virtud de nombramiento legal [la cursiva es mía]») para concluir que «disposición inmediata de la ley es una fórmula jurídico-formal — hoy en día reducida a una fictio iuris - que contempla cómo un funcionario constituye su relación con el Ente al que se incorpora. La citada expresión se refiere a la resolución u Orden Ministerial que se publica en el BOE indicativa de un nombramiento legal». 
sentido, la «elección» se refiere a aquellos sujetos cuyo nombramiento - o en su caso designación ${ }^{119}$ — es realizado bien directamente por los ciudadanos ${ }^{120}$, bien de forma derivada por sus representantes legítimos (alcaldes, diputados provinciales, senadores representantes de las Cámaras legislativas autonómicas, etcétera ${ }^{121}$ ). En fin, el «nombramiento de autoridad competente» alude a los denominados funcionarios «de empleo» (interinos, contratados administrativos y personal laboral temporal ${ }^{122}$ ), nombrados por autoridad competente en vez de acceder a la función pública como funcionarios de carrera ${ }^{123}$.

Lo expuesto permite concluir que el personal de seguridad privada no puede subsumirse en ninguna de las categorías de sujetos pasivos del art. 550.1 CP, lo que revela la naturaleza autónoma del art. 554.3.b) respecto del atentado «clásico». Los grupos de sujetos pasivos del art. 550.1 y del 554.3.b) no guardan una relación interior, tangente o secante, sino exterior.

B) Atendemos ahora a los elementos objetivos específicos de cada precepto. Por un lado, el atentado «clásico» prevé solo uno, formado por dos condiciones alternativas dirigidas a demarcar las dos concretas situaciones en que la realización de alguna acción típica contra el sujeto pasivo constituye atentado: durante el ejercicio por parte de este de funciones propias de su cargo, o en cualquier otro momento, si la conducta típica se produce con ocasión de aquellas. Por su parte, el art. 554.3.b) prevé dos elementos objetivos propios en forma de condiciones cumulativas: que al tiempo de perpetrarse la conducta típica el sujeto pasivo se encuentre: a) debidamente uniformado y b) desarrollando actividades de seguridad privada en cooperación y bajo el mando de las Fuerzas y Cuerpos de Seguridad. Inevitablemente resurge la misma pregunta: ¿qué relación guardan estos dos preceptos?

Como se dijo, el atentado contra el personal de seguridad privada no es, desde la perspectiva del sujeto pasivo, norma especial respecto al

119 Rebollo Vargas, ibid., p. 319.

120 Hasta el Código penal de 1944, el término «elección» estaba siempre adjetivado por "popular», de modo que solo aquellos sujetos elegidos por sufragio universal de los ciudadanos eran considerados funcionarios públicos "por elección» a efectos penales. Al respecto, véase JaVATO MARTín, A.M.: «El concepto de funcionario público a efectos penales», Revista jurídica de Castilla y León, núm. 23, enero 2011, p. 164.

121 Véanse Queralt JiménEZ, «El concepto penal de...», ibid., p. 488, JaVATo Martín, «El concepto de funcionario...», ibid., pp. 164-165, y RAMón RiBAS, ibid., pp. 197-198.

122 Véase VAlEIJE Álvarez, ibid., p. 458: «[...] englobando, por tanto, todas aquellas personas que trabajan al servicio de un ente público de mano pública, aunque su relación laboral se regule por el Estatuto de los Trabajadores y los conflictos que de aquella se deriven se sometan al conocimiento de los tribunales de lo social».

123 Véanse Rebollo Vargas, ibid., p. 320, así como ValeiJe Álvarez, ibid., p. 456: «[e] sto es, un sujeto que aparte de ser Autoridad (o sea, aparte de gozar de mando y jurisdicción) tiene competencia o atribución legítima para adscribir un sujeto al concreto empleo público y para crear una relación jurídica válida». 
atentado "clásico», sino autónoma. Echando un vistazo a los elementos objetivos específicos del resto del Capítulo II, Título XXII, esta tesis parece reforzarse. En efecto, tanto la condición alternativa del art. 550.1 como las cumulativas del 554.3.b) guardan un objetivo común: acotar el ámbito de aplicación de los supuestos de hecho de las normas mediante la exigencia de ciertas condiciones objetivas que, indiciariamente, prevén la lesividad del bien jurídico protegido en el caso concreto. Idéntica lógica se desprende asimismo de las condiciones propias fijadas por los arts. 554.1 -vestir uniforme y encontrarse prestando un servicio legalmente encomendado al tiempo de la conducta típica - y 554.3.a) —encontrarse interviniendo con ocasión de un siniestro, calamidad pública o situación de emergencia-.

Por lo tanto, la conclusión ha de ser aquí idéntica: el inciso del art. 550.1 CP «cuando se hallen en el ejercicio de las funciones de sus cargos o con ocasión de ellas» no resulta aplicable a ninguno de los supuestos del art. 554, pues todos ellos cuentan ya con condiciones propias de análoga naturaleza dirigidas al mismo fin: establecer, según el caso, los concretos términos en que el legislador quiere dispensar la «protección» penológica de los arts. 550.1 y $551 \mathrm{CP}$ a ciertos sujetos pasivos.

\section{Conductas típicas del artículo 554.3.b) del Código Penal}

Perfilada la naturaleza del art. 554.3.b) respecto del atentado «clásico», abordamos al fin el extremo más problemático de este estudio: sus modalidades comisivas. En ambos preceptos nos encontramos ante tipos mixtos con tres modalidades alternativas: acometer, agredir u oponer resistencia grave mediante violencia o intimidación grave (art. 550.1), y acometer, emplear violencia o intimidar gravemente (art. 554.3.b).

Un simple vistazo a cada haz de conductas típicas nos advierte ya el problema: los arts. 550.1 y 554.3 —ubicados en el mismo capítulo del mismo título del Código, reguladores ambos de supuestos del mismo delito- no se hablan en lo fundamental: los verbos típicos. De esta autonomía habíamos dado cuenta en apartados anteriores, pero entonces la cuestión era otra. La distinta vinculación de cada grupo de sujetos pasivos con el bien jurídico protegido es precisamente lo que justifica crear tipos especiales o autónomos de atentado, pivotando cada uno desde el sujeto pasivo al que "protegen». Por el mismo motivo, los elementos objetivos específicos también pueden ser distintos. Pero si resulta que las modalidades comisivas de ambos preceptos guardan íntima relación histórico-legislativa, cuando no se llaman directamente igual, resulta casi imposible no buscar una cierta integración.

Y aquí dimos en el hito, pues ambos catálogos de conductas típicas solo coinciden en una de sus modalidades: el acometimiento. Las otras dos formas de cometer el atentado del art. 554.3.b) —empleo de violencia 
e intimidación grave - fueron modalidades de atentado «clásico» hasta la LO 1/2015, mientras que las dos nuevas previstas en el art. 550.1 —agredir y oponer resistencia grave mediante violencia o intimidación - se han construido a partir de retazos de las cuatro modalidades canónicas desde 1870. En resumen, la asimetría entre las conductas típicas de los arts. 550 y 554.3.b) CP ocasiona toda una serie de problemas interpretativos a cuyo estudio dedicamos los apartados siguientes.

Aunque en lo sucesivo nos centremos en el art. 554.3.b), casi todo lo que se diga vale igualmente para los arts. 554.2 y 554.3.a).

\subsection{Conductas típicas del art. 550 en el CP de 1995}

Puestos a delimitar los verbos típicos del art. 554.3.b), resulta obligado remitirse al estudio del art. 550 en su redacción anterior a la LO 1/2015. Como es sabido, el art. 550 contenía un tipo mixto alternativo con cuatro modalidades comisivas: acometer al sujeto pasivo, emplear fuerza contra él, intimidarlo gravemente u oponerle resistencia activa grave. Salvo por el inciso de que la resistencia grave debía ser también activa, la redacción de las conductas era idéntica a la ya empleada en los Códigos de 1932, 1944 y $1973^{124}$, razón que permitió amortizar la jurisprudencia y trabajos doctrinales históricos dedicados al deslinde de cada una de las acciones típicas - si bien tampoco esto aclaró en exceso las cosas, como se verá enseguida-.

En principio, las cuatro modalidades de atentado aceptan la subsunción de hechos en los que se ejerce fuerza física ${ }^{125}$; el criterio para delimitar cada conducta debe, pues, cifrarse en otros factores. Aquí empiezan los problemas: por un lado, el catálogo típico resulta en extremo confuso, con conceptos imprecisos que por momentos no se sabe si son tangentes, secantes o directamente interiores unos respecto de los otros ${ }^{126}$; por otro, la jurisprudencia ha tendido a mostrarse más bien errática, poco precisa y a veces embrolladora a la hora de deslindar cada modalidad típica de atentado ${ }^{127}$.

${ }^{124}$ Véase al respecto la redacción de los arts. $258.2{ }^{\circ} \mathrm{CP} 1932,231.2{ }^{\circ} \mathrm{CP} 1944$ y $231.2 .{ }^{\circ}$ CP 1973.

125 Pues, como se verá enseguida, dentro de la intimidación grave caben ciertas conductas de fuerza física sobre las cosas.

126 En opinión de GaRCía RIVAS, este «cuadro de conductas y figuras punibles ha servido para generar una jurisprudencia salpicada de matices y vaivenes, incapaz de garantizar la saludable certeza en la aplicación de la ley penal, derecho fundamental del ciudadano», GARCÍA RIVAS, N.: «Delitos de atentado, resistencia y desobediencia», en QUINTERo Olivares, G. (dir.): Comentario a la reforma penal de 2015, Ed. Thomson Reuters, Cizur Menor, 2015, p. 770.

127 Véase, por ejemplo, la jurisprudencia citada en la nota 142 a propósito de la distinción entre las modalidades típicas de empleo de fuerza y acometimiento. 
En primer lugar, la resistencia activa grave se distingue del resto de modalidades por la preexistencia de una pretensión o actuación en curso $^{128}$ no radicalmente nula ni notoriamente extralimitada ${ }^{129}$ por parte del sujeto activo, frente a la cual se ejerce una oposición activa y grave ${ }^{130}$ que podrá consistir o no en un acto de violencia. El inciso «grave» facilita la distinción con el delito de resistencia del antiguo art. $556 \mathrm{CP}^{131}$, si bien no impide que cierta jurisprudencia califique como acometimiento, en razón de la fuerza empleada ${ }^{132}$ o lo sorpresivo del ataque ${ }^{133}$, lo que en puridad son conductas de resistencia. Por su parte, el inciso "activo» ayuda a deslindar la resistencia como atentado de la desobediencia grave, consistente en una mera omisión ante el mandato autoritario «sin llegar a oposición material o de contrafuerza que lo neutralice» ${ }^{134}$, lo cual también genera problemas de deslinde con el acometimiento que enseguida veremos.

En segundo lugar, el acometimiento se define como «ataque», «embestida» u otra acción de violencia física ${ }^{135}$ que revele un propósito de

$128 \mathrm{Al}$ respecto, véanse ÁlVAREz García, F.J./CARRASCo ANDRINo, M.M.: «Delimitación de las modalidades de conducta en el delito de atentado: el significado de agredir, acometer y oponer resistencia», en ÁlVAREZ GARCÍA, F.J. (dir.): Tratado de Derecho penal español. Parte especial. V, Ed. Tirant lo Blanch, Valencia, 2018, pp. 13-14 del original; LoRENTE VeLAsco, ibid., pp. 198-200; así como la SAP-Madrid, Sección 30. a, 402/2016, de 10.6, la SAP-Barcelona, Sección 6. a , 4/2011, de 30.12 de 2010 y la STS 261/2013, de 27.3.

129 Para un amplio sector doctrinal, existe un derecho de resistencia del particular en los casos de nulidad radical o notoria extralimitación en la actuación del sujeto pasivo. «En tales casos, la ilegitimidad de la actuación provocará la falta de un elemento del tipo: el funcionario no se hallará en el ejercicio de funciones públicas», CARBONELL MATEU, J.C./ Vives ANTÓn, T.S.: «Delitos contra el orden público», en Vives ANTÓn, T.S. y otros: Derecho Penal. Parte Especial, Tirant lo Blanch, 2010, p. 768. En el mismo sentido, véanse QuiNTERo Olivares, Comentarios a la parte especial..., ibid., p. 2074; el mismo, en Quintero Olivares, G. (dir.): Comentarios al Código Penal Español, Tomo II, Ed. Thomson Reuters, Cizur Menor, 2016, p. 1774; Zárate Conde, ibid., p. 967; Lamarca Pérez, ibid., p. 850; MuNoz Conde, ibid., p. 747; Prats Canut, M., en Quintero Olivares, G. (dir.): Comentarios

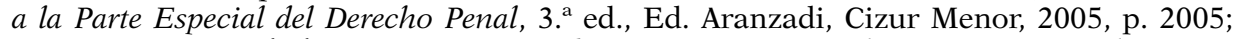
BeNítez ORTÚZAR, ibid., p. 1347, así como las SSTS 1042/1994, de 20.5, 191/1995, de 14.2, y 466/2013, de 4.6. Por su parte, el Tribunal Supremo ha establecido que la extralimitación llamada leve no comporta la atipicidad del atentado (por todas, STS de 21.6 de 1989), si bien puede invocarse la causa de justificación de legítima defensa o, más comúnmente, la de estado de necesidad.

${ }_{130} \mathrm{Al}$ respecto véanse Llobet Anglí, ibid., pp. 388-389; Goyena Huerta, ibid., p. 3; BeNíTEZ ORTÚZAR, ibid., p. 1346, así como las SSTS 218/2003, 18.2, y 819/2003, de 6.6.

131 Al respecto véanse Quintero Olivares, Comentarios a la parte especial..., ibid., 2016, p. 2073, y Benítez OrTúzar, ibid., p. 1354, así como la SAP-Madrid, Sección 30. , $402 / 2016$, de 10.6 y la STS 607/2006, de 4.5 .

132 Véanse las SSTS 1285/2003, de 3.10, 80/2004, de 2.2, o 1427/2004, de 10.12.

133 Véanse la SAP-Islas Baleares, Sección 1. a , 6/2016, de 25.1, y la STS 256/2004, de 25.2, así como las ya citadas SAP-Barcelona, Sección 6. ${ }^{\text {, }}$ 4/2011, de 30.12 de 2010 y SAPMadrid, Sección 30. a , 402/2016, de 10.6.

${ }_{134}$ Al respecto véase PRATS CANUT, ibid., p. 2003, así como la jurisprudencia allí citada.

135 Véase Álvarez García/Carrasco Andrino, «Delimitación de las...», ibid., p. 10 del original, así como las SSTS 432/2000, de 18.3, y 256/2004, de 25.2. 
lesionar al sujeto pasivo ${ }^{136}$, aunque la lesión no llegue a consumarse ${ }^{137}$. Basta, pues, con una conducta de mera iniciación del ataque o movimientos reveladores de propósito agresivo, contenido que puede llegar a solaparse con el ámbito de la intimidación grave (piénsese en sujetos pasivos que portan objetos peligrosos: ¿en qué momento acaba la intimidación y empieza el acometimiento?). Sobre la entidad lesiva que deba revestir la conducta típica no existe acuerdo jurisprudencial ${ }^{138}$ : no se exige la efectiva lesión del sujeto pasivo, pero sí al menos un acto de violencia física contra este, que también podrá perpetrarse a través de instrumentos, objetos o animales ${ }^{139}$. Por su parte, un amplio sector doctrinal entiende que la agresión se considera integrante de la modalidad de acometimiento ${ }^{140}$, motivo por el que la jurisprudencia venía aplicando exclusivamente a esta figura la agravante de agresión con armas u otros medios peligrosos, residenciada en el antiguo art. 552.1. ${ }^{\mathrm{a}} \mathrm{CP}^{141}$.

En tercer lugar, el empleo de fuerza consiste en un acto de violencia física contra el sujeto pasivo («empleen fuerza contra ellos»" ${ }^{142}$, rezaba el tenor literal del art. $550 \mathrm{CP}$ ). Este inciso clarifica el deslinde con la intimidación, en la que la violencia física, de darse, se circunscribe a la fuerza en las cosas. No es pacífico sin embargo el deslinde con el acometimiento, ni por ende con la agresión. Algún autor entiende que el acometimiento persigue la lesión del sujeto pasivo - aunque no se materialice-, mientras que el empleo de fuerza se dirige más bien a do-

136 Véanse, por todas, las SSTS 580/2014, de 21.7, 672/2007, de 19.7, 146/2006, de 10.2, y 309/2003, de 15.3 .

137 En este sentido véanse Prats Canut, ibid., p. 2001, o Quintero Olivares, Comentarios al Código Penal..., ibid., 2016, p. 1771, así como las SSTS 328/2014, de 28.4, 672/2007, de 19.7 y 309/2003, de 15.3.

138 Al respecto, cierta jurisprudencia no ha considerado atentado una bofetada (STS 920/1996, de 25.11), un forcejeo con codazo en el estómago (STS 883/2008, de 17.12) o un manotazo (STS 328/2014, de 28.4), mientras que otra sí ha calificado de atentado un fuerte codazo (STS 153/2012, de 2.3), un pisotón (SAP Islas Baleares, Sección 1. a , 151/2015, de 27.5), o una bofetada y un empujón (SAP Madrid, Sección 29. a , 119/2016, de 3.3).

139 «La jurisprudencia ha equiparado el acometimiento mediante actos corporales (puñetazo, patada), con la utilización de medios agresivos materiales» (por todas, STS 98/2007, de 16.2, y STS de 18.3 de 2000).

140 Véanse por todos Llobet Anglí, ibid., p. 388; Quintero Olivares, Comentarios a la parte especial..., ibid., 2016, pp. 2072-2073; y PRATS CANUT, ibid., p. 2001. Sin embargo, la agresión posee un contenido más amplio que el acometimiento para Cuerda Arnau, M.L.: «Una reforma autoritaria del delito de atentado», en BACIGALUPO SAGESSE, ibid., pp. 823824; Carretero Sánchez, ibid., p. 10; De la Cuesta Aguado, P.: «Atentado, resistencia y desobediencia», en Álvarez GaRCíA, F.J. (dir.): Estudio crítico sobre el anteproyecto de reforma penal de 2012, Ed. Tirant lo Blanch, Valencia, 2013, pp. 963-964, o Álvarez GARCía/ CARRASCO ANDRINO, «Delimitación de las...», ibid., p. 8 del original.

141 Por todas, véanse las SSTS 664/2010, de 4.6 («tijeras de $15 \mathrm{~cm}$ ), y 294/2012, de 26.4 («un tubo metálico»).

${ }_{142}$ Y no dirigida a las cosas, como se admite en ocasiones respecto de, por ejemplo, las coacciones. En este sentido, véase Quintero Olivares, Comentarios al Código Penal..., ibid., 2016, p. 1772. 
blegar la voluntad del sujeto pasivo ${ }^{143}$; otro sugiere que el acometimiento es instantáneo y el empleo de fuerza requiere de una mayor duración ${ }^{144}$. En todo caso, la jurisprudencia ${ }^{145} \mathrm{y}$ un sector doctrinal ${ }^{146}$ tienden a usar ambos términos como sinónimos.

Y en cuarto lugar, la intimidación grave se entiende como «el anuncio o conminación de un mal inminente, grave, concreto y posible, susceptible de una coacción anímica intensa» ${ }^{147}$, propósito emisible a través del uso de ciertos objetos, animales, o mediante el ejercicio de violencia sobre las $\operatorname{cosas}^{148}$. Para que la intimidación sea típica basta, como en el acometimiento, con que la conducta sea apta para amedrentar al sujeto pasivo, aunque no llegue a producirse dicha perturbación anímica ${ }^{149}$; este hecho dificulta aún más, como se verá después, el deslinde con aquella figura. En cuanto a la gravedad de la intimidación, se trata de una gradación normativa que habrá de apreciarse caso a caso, partiendo de factores como la importancia del mal, los objetivos o medios empleados o el tiempo y lugar en que se desarrolla la intimidación ${ }^{150}$.

Como es sabido, el esquema recién expuesto fue modificado por la LO 1/2015, al reducirse — que no reconducirse ${ }^{151}$ — las modalidades típicas del art. 550.1 CP a tres: el acometimiento, la agresión y la resistencia

143 Véanse al respecto Álvarez García/CarRasco ANDrino, «Delimitación de las...», ibid., p. 3 del original, así como Carbonell Mateu/Vives Antón, Comentarios al Código Penal de 1995..., ibid., p. 2073.

144 Véase al respecto Prats CANUT, ibid., p. 2002.

145 Por todas, la SAP-Madrid, Sección 16. ${ }^{\text {a }, 208 / 2008, ~ d e ~} 3.4$ (morder la mano del agente al ser detenido) y SAP-Santa Cruz de Tenerife, Sección 5. ${ }^{a}, 139 / 2008$, de 29.2 (abalanzarse contra el agente, golpeándole y causándole lesiones) califican por acometimiento, mientras que la SAP-Murcia, Sección 2. ${ }^{a}, 44 / 2005$, de 9.5 (dar patadas al agente) o la SAPMálaga, Sección $3 .{ }^{\mathrm{a}}, 90 / 2005$, de 8.2 (dar un puñetazo en el pecho al agente) califican por empleo de fuerza.

$146 \mathrm{Al}$ respecto, véanse por todos Benítez ORTÚZAR, ibid., p. 1346, así como el informe del Consejo General del Poder Judicial al anteproyecto de Ley Orgánica por la que se modifica la Ley Orgánica 10/1995, de 23 de noviembre, del Código Penal, p. 251.

147 Definición canónica extraída de la STS 660/2001, de 18.4.

148 La casuística de esta modalidad es prácticamente infinita: desde esgrimir un gran cuchillo (SAP-Sevilla, Sección 3. ${ }^{2}$, 459/2006, de 18.9), un palo en compañía de dos mastines (SAP-Asturias, Sección 2. a , 29/2007, de 1.2), un palo solamente (SAP-Sevilla, Sección $1 .^{a}, 11 / 2000$, de 13.1), un arma blanca (STS 1672/2000, de 30.10), un arma de fuego (SSTS 230/1997, de 19.2, o 456/1999, de 23.3), un sillón (SAP-Ciudad Real, Sección 2. a , 139/2000, de 9.10) o una bombona de butano (SAP-Cádiz, Sección 1. a , de 5.4.2003).

149 Al respecto véase PRATS CANUT, ibid., p. 2002, así como la jurisprudencia allí citada.

150 Al respecto véanse Lorente Velasco, ibid., p. 193; Vives Antón/Carbonell Mateu, Comentarios al Código Penal de 1995..., ibid., p. 2074; y Prats CANutS, ibid., p. 2457.

151 Pues, como se verá más adelante, las conductas de intimidación grave no constitutivas de acometimiento, agresión ni resistencia quedan con la reforma extra muros del delito de atentado. A este respecto, véanse Cuerda Arnau, M.L.: Derecho penal. Parte especial, 4. ${ }^{a}$ ed., Ed. Tirant lo Blanch, Valencia, 2015, p. 1281; ZÁRATE CONDE, ibid., pp. 959-960; Goyena Huerta, ibid., p. 4; Carretero Sánchez, ibid., p. 3; Muñoz Conde, ibid., pp. 746747, así como la Consulta 1/2017 de la Fiscalía General del Estado, pp. 5-6. 
grave mediante intimidación grave o violencia ${ }^{152}$. Según se expresó más arriba, el acometimiento resulta ser la única de estas conductas incluida asimismo en el catálogo del art. 554.3.b), circunstancia problemática que merecerá la atención preeminente de las siguientes líneas. Con respecto a la intimidación grave o al empleo de violencia, baste decir que el contenido de las conductas típicas expuesto a propósito del antiguo art. $550 \mathrm{CP}$ resulta perfectamente extrapolable a las modalidades cuasi homónimas del art. 554.3.b), por lo que no procede mayor consideración. En cuanto a la omisión de la resistencia grave, su oportunidad será objeto de otro apartado.

De lo expresado hasta ahora puede extraerse una segunda conclusión: para poder interpretar el art. 554.3.b) CP habrá que acudir, según los casos, a los trabajos y jurisprudencia sobre una redacción vigente o derogada del delito de atentado «clásico».

\subsection{El acometimiento en el artículo 554.3.b) del Código Penal}

La nueva configuración típica del art. $550.1 \mathrm{CP}$ afecta particularmente al acometimiento. De un lado, este ve recortado su significado en tanto que la agresión se escinde de él para adquirir autonomía como conducta típica. De otro, la supresión de la intimidación grave como conducta autónoma plantea que aquellas conductas otrora limítrofes con el acometimiento puedan caer en el ámbito de este. En conjunto, los perfiles del acometimiento se desdibujan a efectos del art. 550, y en principio a los del art. 554.3.b).

\subsection{1. ¿Acometimiento sin agresión?}

En primer lugar, debe distinguirse el acometimiento de la agresión. Dada la estructura del antiguo art. $550 \mathrm{CP}$, esto nunca llegó a ser una cuestión apremiante - de hecho, para un cierto sector doctrinal ${ }^{153}$ y jurisprudencial ${ }^{154}$ este debate tampoco debe serlo ahora pues ambos tér-

152 En la redacción introducida por la LO 1/2015 se suprime el inciso de que la resistencia grave deba ser «activa», si bien la doctrina mayoritaria entiende que esta resistencia, en tanto que ejercida mediante intimidación grave o violencia, siempre lo será. En este sentido, véanse Cuerda ARnau, Derecho penal..., ibid., p. 1271; Cuerda ARnau, Una reforma..., ibid., p. 824; Goyena Huerta, ibid., p. 2; y ZÁrate Conde, ibid., p. 960, así como la STS 534/2016, de 17 de junio.

153 Al respecto, véanse Benítez Ortúzar, ibid., p. 1346; Cuerda ARnAu, Una reforma..., ibid., p. 824; la misma: «Atentados y resistencia (arts. 550 y ss.)», en GonZÁlez CUSSAC, J.L.

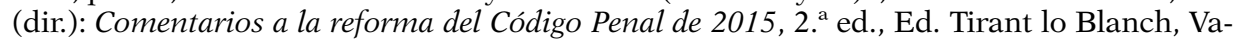
lencia, 2015, pp. 1282-1283; García Rivas, ibid., p. 771; y Quintero Olivares, Comentarios al Código Penal..., ibid., 2016, p. 1771.

154 Por todas, véase el tenor de las SSTS 580/2014, de 21.7, y 328/2014, de 28.4: «Acometer equivale a agredir y basta con que tal conducta se dé con una acción directamente dirigida a agredir a la Autoridad». 
minos serían sinónimos o directamente metonímicos. La mención típica a la agresión resultaría entonces superflua, y en la práctica estaríamos ante un tipo con solo dos conductas típicas: ejercer resistencia grave y acometer-agredir, según se resuelva la metonimia ${ }^{155}$. Sin embargo, cabe asimismo dotar a cada concepto de un contenido propio, ajustándose en la medida de lo posible a la tradición interpretativa. A nuestro modo de ver, esta elección resulta más depurada desde la exigencia del principio de legalidad penal (art. 25.1 CE), máxime teniendo en cuenta que, suprimida la intimidación grave como conducta autónoma, el concepto de acometimiento del art. 550 ya necesita por fuerza reformularse.

En esta línea, un cierto sector ha optado por traspasar a la agresión el contenido típico del antiguo empleo de fuerza ${ }^{156}$. Sin embargo, esta opción presenta una clara desventaja: el significado de empleo de fuerza no es nada pacífico, por lo que la transustanciación de su contenido en agresión difícilmente clarificaría las cosas. Algún otro autor, partiendo del distinto alcance de la agresión en otros lugares del Código (legítima defensa, delitos contra la libertad e indemnidad sexuales), sugiere que esta se identifique con la más amplia noción de «ataque», que incluiría conductas más allá del acometimiento como la intimidación, los ataques por autoría mediata o el ejercicio de violencia sobre cosas que afecta al sujeto pasivo ${ }^{157}$. Esta postura resuelve satisfactoriamente el problema de delimitación de cada figura típica a efectos del art. 550 CP: el acometimiento se circunscribiría a los actos de «embestida» o "arrojamiento», en fin, de violencia física al sujeto pasivo; la agresión, al resto de ataques contra el sujeto pasivo - violencia psíquica, autoría mediata o fuerza en las cosas, entre otros-; y la resistencia grave, a las conductas violentas o gravemente intimidatorias que se sustancien tras un requerimiento previo por parte del sujeto pasivo. Al éxito de esta solución contribuye en gran medida la supresión de la intimidación grave y el empleo de fuerza como modalidades típicas autónomas del art. 550.1, circunstancia que, salvo reformulaciones doctrinales, dejaba técnicamente en el limbo toda una serie de conductas anteriormente típicas. Con el nuevo esquema, en resumen, algunas de estas podrían reconducirse al ámbito típico de la agresión ${ }^{158}$.

$155 \mathrm{Al}$ respecto, véase ÁlVARez García/CARrasco Andrino, «Delimitación de las...», ibid., pp. 6-7 del original.

156 Véanse Vázouez González, ibid., p. 823; Terradillos Basoco, J.M./Gallardo García, R.M.: «Delitos contra el orden público (I)», en Terradillos Basoco, J.M. (coord.): Lecciones y materiales para el estudio del Derecho penal, tomo III, Derecho penal, Parte Especial, vol. II, p. 375, así como el informe del Consejo Fiscal al Anteproyecto de Ley orgánica por la que se modifica la Ley orgánica 10/1995, de 24 de noviembre, del Código Penal, p. 314.

157 Véase Álvarez García/CARRasco ANDrino, «Delimitación de las...», ibid., pp. 8-9 del original.

158 En concreto, las conductas de intimidación grave no constitutivas de resistencia podrían concebirse como agresiones en su modalidad de ataque violento psíquico; en cuanto a las de empleo de fuerza, su subsunción resulta totalmente limpia. Al respecto véase ÁLVAREZ GARCÍA/CARRASCO ANDRINO, «Delimitación de las...», ibid., pp. 10-11 del original. 
Dicho lo cual, ocurre que las modalidades de intimidación grave y violencia física sí que se encuentran vigentes en el tipo del art. 554.3.b) CP. Es decir, que a efectos de tal precepto:

a) la agresión no constituye una modalidad típica autónoma;

b) la intimidación grave y el empleo de violencia sí lo son, y, por consiguiente,

c) la agresión no puede atraer hacia sí conductas pertenecientes al ámbito de otras modalidades típicas vigentes.

Dando por buenos estos silogismos, la interpretación más lógica de la actual asimetría entre las conductas típicas de los arts. 550 y 554.3.b) CP sería, a mi juicio, que el legislador de la LO 1/2015 decidió escindir la agresión del acometimiento a todos los efectos, es decir, con consecuencias para todos los preceptos del Capítulo II, Título XXII. De lo contrario se estaría afirmando que o bien el legislador «olvidó» mencionar la agresión en el art. 554.3 CP — ¿impensable? - o bien la omitió adrede de este precepto pensando que el acometimiento, rodeado de las acciones típicas del antiguo art. 550, sería interpretado como inclusivo de la agresión —con lo cual se introducirían deliberadamente en el mismo capítulo y título del Código dos conceptos de distinto significado pero idéntica denominación: igualmente impensable-. Descartadas tales opciones, la «lógica» solo nos ofrece que:

a) a efectos del art. $550 \mathrm{CP}$ quedan impunes ciertas conductas de empleo de violencia o intimidación grave no consistentes en resistencia, concretamente las que no puedan reconducirse como agresiones o acometimientos, y

b) a efectos del art. $554.3 \mathrm{CP}$, dado que el empleo de violencia y la intimidación grave sí se hallan expresamente en el tipo, la agresión se entiende excluida como modalidad típica, incluso como forma de acometimiento.

Esta interpretación, quizá precisamente por ser la más lógica, cuestiona sin embargo el propósito declarado por el legislador en la Exposición de motivos de la LO 1/2015: «se introduce una nueva definición del atentado que incluye todos los supuestos de acometimiento, agresión, empleo de violencia o amenazas graves de violencia sobre el agente». Parece que la reforma de las conductas típicas del atentado se proponía, como mínimo, conservar el rango de situaciones típicas ya previstas por el antiguo art. 550; y sin embargo, no pocos autores señalan que el efecto ha sido precisamente el contrario ${ }^{159}$. En este sentido, y al margen de lo

159 Al respecto, véanse por todos De la Cuesta Aguado, ibid., p. 964; y García RiBas, ibid., p. 772, que hacen referencia a ciertas conductas antiguamente residenciadas en la intimidación grave autónoma (acciones aisladas o de acoso en núcleos poblacionales pequeños con escasas dotaciones de agentes) que con la regulación actual no serían subsumibles en el atentado. 
que es estricta política criminal, cabe señalar que si finalmente se consiguen reconducir al atentado «todos los supuestos de acometimiento, agresión, empleo de violencia o amenazas graves de violencia» no será, como pretende la Exposición de motivos, gracias a la definición del nuevo art. 550.1 CP — que precisamente convierte la intimidación grave y el empleo de violencia en meras formas de oponer resistencia-, sino a la interpretación doctrinal y jurisprudencial del nuevo catálogo de modalidades comisivas.

En aras de preservar el derecho de todos a la legalidad penal (art. 25.1 CE) puede concluirse aquí que la conducta típica de acometimiento del art. 554.3.b) CP no contiene - por coherencia con la redacción del art. $550.1 \mathrm{CP}$ - a la agresión.

\subsubsection{Acometimiento y casos frontera con la intimidación grave}

En segundo lugar, procede valorar la supresión de la intimidación grave como conducta autónoma en la medida en que esto afecta al ámbito típico del acometimiento. Ya se dijo que ambas figuras se solapaban en ocasiones: en concreto, y pese al componente físico indiscutible que debe revestir el acometimiento, la yuxtaposición se produce en aquellas conductas gravemente intimidatorias que además pueden entenderse como actos formales de iniciación del ataque o movimientos reveladores del propósito agresivo (v.g., encañonar al agente con un revólver, esgrimir con propósito agresivo un machete, o azuzar a un perro de raza peligrosa).

Como se comentó arriba, el concepto de agresión del art. $550.1 \mathrm{CP}$ es susceptible de absorber ciertas conductas de empleo de violencia o intimidación grave no constitutivas de resistencia. ¿Lo es también el acometimiento? Este parece ser el criterio de la Fiscalía General del Estado en su Consulta 1/2017 ${ }^{160}$ : la intimidación grave puede incardinarse en el acometimiento cuando la conducta se enmarque en un mero acto formal de iniciación del ataque o en movimientos reveladores del propósito agresivo. En esta línea parece posicionarse asimismo la STS 338/2017, de 11.5, al señalar que el «acometimiento se parifica con la grave intimidación, que puede consistir en un mero acto formal de iniciación del ataque o en un movimiento revelador del propósito agresivo». Con la intimidación grave autónoma desparecida del art. 550.1, el problema a la hora de calificar estos supuestos fronterizos parece desvanecerse: en adelante serán constitutivos de acometimiento ${ }^{161}$.

160 Véase la Consulta 1/2017 de la Fiscalía General del Estado, p. 6.

161 Por contra, si la exteriorización del propósito de causar un mal grave, posible y que reviste apariencia de seriedad y firmeza no va acompañado de movimientos reveladores del propósito agresivo ni implica un acto formal de iniciación del ataque, ni está unido a una resistencia grave, ni puede reconducirse a la agresión en su vertiente de violencia 
Por lo tanto, el concepto de acometimiento del art. 550.1 CP es susceptible de integrar ciertas conductas que anteriormente se residenciaban en la intimidación grave. Sin embargo, al tratar de extrapolar este resultado al art. 554.3.b) nos encontramos de nuevo con el mismo problema: la modalidad comisiva de intimidación grave sí está vigente en este último precepto. Así, la polémica sobre los supuestos frontera entre ambas modalidades comisivas debe entenderse plenamente vigente en el art. 554.3.b): tanto el acometimiento como la intimidación resultan idóneos para englobar las conductas gravemente intimidatorias consistentes en actos formales de iniciación de un ataque o movimientos reveladores de un propósito agresivo. Por ello, tales conductas no pueden pasar indefectiblemente a integrar el contenido típico del acometimiento; el asunto queda, una vez más, en manos de la casuística jurisprudencial.

La lógica aplicada hasta ahora nos conduce a una conclusión cuanto menos intrépida: en aras de salvaguardar el principio de legalidad penal, y atendiendo en lo posible a la interpretación tradicional de las modalidades típicas, deben ahora convivir en el mismo capítulo y título del Código dos conceptos distintos de acometimiento: uno para los arts. 550 y 554.1 CP y otro para los apartados 2 y 3 del propio 554 CP. Pese a lo singular de la situación, no se me ocurre solución más coherente a la vista de todo lo expresado.

\subsubsection{La omisión de la resistencia en el artículo 554.3 del Código Penal}

Como cierre a este análisis de las modalidades típicas del art. 554.3.b) $\mathrm{CP}$, cabe referirse brevemente a la omisión de la resistencia activa, modalidad sí presente en el art. 550.1 CP.

Dando por sentado que no se trata de un «olvido», debe señalarse que esta decisión resulta a mi juicio incoherente con la voluntad expresa del legislador de la LO 1/2015 de equiparar penalmente - bajo ciertos requisitos- la «protección» del personal de seguridad privada y la de los sujetos pasivos recogidos en el art. $550.1 \mathrm{CP}^{162}$. Y ello porque, conforme a la regulación vigente, el personal de seguridad privada se encuentra habilitado para ejercitar toda una serie de pretensiones y actuaciones contra el potencial sujeto activo del delito de atentado, actuaciones que perfectamente encajan como prerrequisito frente al que oponer resistencia

\footnotetext{
psíquica, los hechos solo podrían ser constitutivos, en su caso, de un delito de amenazas. Como ha señalado algún autor, en la práctica existen supuestos de intimidación grave sin resistencia, acometimiento ni agresión que con la reforma quedan despenalizados. Por todos, véanse de nuevo De la Cuesta Aguado, ibid., p. 964; y García Ribas, ibid., p. 772.

162 Concretamente, reza el tenor de la Exposición de motivos de la LO 1/2015: «quien [...] asume en determinadas condiciones el desempeño de funciones públicas o de gran relevancia social, debe recibir una protección equivalente a la de aquellos que intervienen con carácter oficial» (la cursiva es mía).
} 
activa. Entre ellas cabe destacar, por ser las que se prestan a más clara analogía con actividades propias de las Fuerzas y Cuerpos de Seguridad, las siguientes:

a) «efectuar controles de identidad, de objetos personales, paquetería, mercancías o vehículos, incluido el interior de estos [...]. La negativa [...] facultará para impedir a los particulares el acceso o para ordenarles el abandono del inmueble o propiedad objeto de su protección» (art. 32.1.b) LSP);

b) «evitar la comisión de actos delictivos o infracciones administrativas en relación con el objeto de su protección [...], debiendo oponerse a los mismos e intervenir cuando presenciaren la comisión de algún tipo de infracción» (art. 32.1.c) LSP), o

c) «en relación con el objeto de su protección o de su actuación, detener y poner inmediatamente a disposición de las Fuerzas y Cuerpos de Seguridad competentes a los delincuentes» (art. 32.1.d) LSP).

Podría pensarse que la exclusión de la resistencia del art. 554.3.b) obedece simplemente a la especial —menos intensa- relación del sujeto pasivo con el bien jurídico protegido en dicho precepto. En efecto, si la LSP previera que el personal de seguridad privada no participase sino incidentalmente en tareas de seguridad ciudadana, y siempre "en cooperación y bajo el mando de las Fuerzas y Cuerpos de Seguridad», podría pensarse que su "protección» penal no requiere la inclusión de los supuestos de resistencia activa, dada la escasa lesividad que estos supondrían para el bien jurídico protegido. En suma, la modalidad de resistencia activa grave solo se tipificaría respecto de aquellos sujetos pasivos que ostenten verdadera auctoritas en el desempeño de sus funciones (ciertas autoridades, agentes de la autoridad y funcionarios públicos, y en su caso los miembros de las Fuerzas Armadas); este parecer ser por cierto el criterio del legislador: es exactamente así como distribuye la inclusión de la resistencia activa grave a lo largo del Capítulo II, Título XXII ${ }^{163}$. Sin embargo, no puede compartirse aquí esa opción legislativa.

Como se expresó en otro epígrafe, nuestra Constitución solo contempla la noción de seguridad pública, competencia atribuida en exclusiva al Estado (art. 149.1 29. ${ }^{\mathrm{a}} \mathrm{CE}$ ). Así parece entenderlo la LSP al establecer que la seguridad privada constituye un recurso externo de la pública (art. 4.c) LSP), es decir, parte integrante de la misma. De este modo, si

163 En efecto, no se prevé tal modalidad ni en el art. 554.2 (quienes actúan en auxilio de los sujetos pasivos del atentado «clásico») ni en el 554.3.a) (bomberos o miembros del personal sanitario o equipos de socorro) ni en el 554.3.b) (personal de seguridad privada), pero sí en el 550.1 (autoridades, funcionarios públicos y agentes de la autoridad) y el 554.1 (miembros de las Fuerzas Armadas). 
los vigilantes de seguridad (y en su caso los guardas rurales ${ }^{164}$ ) se encuentran legalmente habilitados para participar en determinadas tareas de seguridad pública, su condición o no de auctoritas no es argumento suficiente para minorarles la «protección» penal. Cuando actúan «en cooperación y bajo el mando de las Fuerzas y Cuerpos de Seguridad» los vigilantes desempeñan una función pública, lo que, por desacertado o incluso inconstitucional que pueda ser, no se soluciona con una aberración jurídica mayor. En tanto que legalmente habilitado para el ejercicio de una serie de actividades de seguridad ciudadana, el vigilante de seguridad se erige en un representante más de esta, y resulta así razonable que su actuación se encuentre "protegida» a tales exclusivos efectos por los mismos mecanismos de prevención general negativa que rigen en favor de los agentes de la autoridad. De lo contrario, la única perjudicada es la seguridad ciudadana.

Recapitulando, el delito de atentado del art. 554.3.b) CP contiene tres modalidades comisivas: la intimidación grave y el empleo de violencia, que heredan el contenido histórico de sus modalidades cuasi homónimas del antiguo art. $550 \mathrm{CP}$, y el acometimiento, que no incluye ni la agresión ni las conductas limítrofes con la intimidación grave como sí hace su homónimo del actual art. 550.1 CP.

\section{Conclusiones}

Las principales aportaciones de este trabajo pueden sintetizarse así:

A) La LSP habilita al personal de seguridad privada para el desempeño de ciertas actividades que materialmente se integran en la noción aquí defendida de seguridad ciudadana. Concretamente, la actividad de seguridad privada de «vigilancia y protección (art. 5.1.a) LSP), desagregada en los servicios de vigilancia y protección (arts. 41.2 y 41.3 LSP) se inscribe claramente en el núcleo de la seguridad ciudadana.

B) El bien jurídico protegido por el delito de atentado contra el personal de seguridad privada es el buen desempeño de la función pública de seguridad ciudadana, conclusión a la que conducen tanto la demarcación del bien jurídico protegido por el Capítulo II, Título XXII del Código — el buen desempeño de las funciones o servicios públicos- como el elemento objetivo específico del art. 554.3.b) CP «desarrolle actividades de seguridad privada», que remite al (plenamente identificable con actividades de seguridad ciudadana) catálogo de actividades del art. 5.1.a) LSP.

164 Como prevé expresamente el art. 41.1 LSP. 
C) $\mathrm{El}$ art. 554.3.b) $\mathrm{CP}$ regula un delito autónomo respecto del atentado «clásico». Por un lado, el personal de seguridad privada no puede subsumirse en ninguna de las categorías de sujetos pasivos del art. $550.1 \mathrm{CP}$, lo que revela la naturaleza autónoma del art. 554.3.b) respecto del atentado «clásico»; por otro, los elementos objetivos específicos de cada precepto cumplen análogo objetivo: establecer, según el caso, los concretos términos en que el legislador quiere dispensar la "protección» penológica de los arts. 550.1 y $551 \mathrm{CP}$ a ciertos sujetos pasivos.

D) De las tres modalidades comisivas previstas en el art. 554.3.b) CP, dos de ellas - la intimidación grave y el empleo de violenciaheredan el contenido histórico de sus modalidades cuasi homónimas del antiguo art. $550 \mathrm{CP}$, y la restante - el acometimientorecibe un contenido propio que no incluye ni la agresión ni las conductas limítrofes con la intimidación grave, como sí hace su homónimo del actual art. 550.1 CP.

\section{Referencias bibliográficas}

AgirReaZKuenaga Zigorraga, I.: «Perfiles y problemática de la seguridad privada en el ordenamiento jurídico español», Revista de Administración Pública, núm. 118, enero-abril 1989.

Álvarez García, F.J. (dir.): Tratado de Derecho penal español. Parte especial. V, Tirant lo Blanch, Valencia, 2018.

—: «La nueva reforma penal de 2013», Eunomía. Revista en Cultura de la Legalidad, núm. 6, marzo-agosto 2014.

- (dir.): Estudio crítico sobre el anteproyecto de reforma penal de 2012, Ed. Tirant lo Blanch, Valencia, 2013.

ARroyo Zapatero, L.: «Principio de legalidad y reserva de ley en materia penal», Revista española de derecho constitucional, núm. 8, 1983.

Bacigalupo Saggese, S. (coord.): Estudios de Derecho Penal: Homenaje al profesor Miguel Bajo, Ed. Universitaria Ramón Areces, Madrid, 2016.

Barcelona Llop, J.: Policía y Constitución, Ed. Tecnos, Madrid, 1997.

- : «La administración de la seguridad ciudadana. Selección de problemas a comienzos del siglo XXI», Revista Vasca de Administración Pública, núm. 64, 2002.

Carbonell Mateu, J.C./Vives Antón, T.S.: Derecho Penal. Parte especial, Ed. Tirant lo Blanch, Valencia, 2008.

CARretero SÁnchez, A.: «El delito de atentado, resistencia y desobediencia a la autoridad y sus agentes tras la reforma del Código Penal», $L a$ Ley, 7745/2015. 
Carro Fernández-Valmayor, J.L.: «Sobre los conceptos de orden público, seguridad ciudadana y seguridad pública», Revista Vasca de Administración Pública, núm. 27, 1990.

Cerezo Mir, J.: Problemas fundamentales del Derecho Penal, Ed. Tecnos, Madrid, 1982.

Cobo del Rosal, M. (coord.): Derecho Penal. Parte Especial, Ed. Dykinson, Madrid, 2004.

Córdoba Roda, J. /Garcia Arán, M. (dir.): Comentarios al Código Penal. Parte general, Ed. Marcial Pons, Madrid, 2011.

Córdoba Roda, J. /Garcia Arán, M.: Comentarios al Código penal. Tomo II, Ed. Marcial Pons, Madrid-Barcelona, 2004.

Córdoba Roda, J. y otros: Comentarios al Código Penal, Tomo II, Ed. Ariel, Barcelona, 1972.

Cuerda Arnau, M.L.: Derecho penal. Parte especial, $4 .^{\text {a }}$ ed., Ed. Tirant lo Blanch, Valencia, 2015.

-: Los delitos de atentado y resistencia, Ed. Tirant lo Blanch, Valencia, 2003.

Gándara Trueba, E.: «La Ley 5/2014, de 4 de abril, de Seguridad Privada», Seguridad y ciudadanía: Revista del Ministerio del Interior, núm. 14, julio-diciembre 2015.

Gil Gil A. /Lacruz López, J.M./Melendo Pardos, M. /NúÑez Fernández,

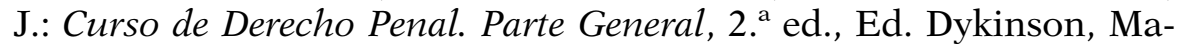
drid, 2015.

Gómez Tomillo, M. (dir.): Comentarios al Código Penal, Ed. Lex Nova, Madrid, 2010.

González Cussac, J.L. (dir.): Comentarios a la reforma del Código Penal de

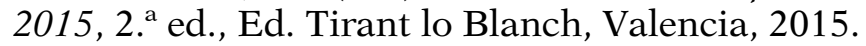

Goyena Huerta, J.: «La reforma del delito de atentado operada por la Ley Orgánica 1/2015», Revista Aranzadi Doctrinal, núm. 9, 2016.

Groizard y Gómez de la Serna, A.: El Código Penal de 1870. Concordado y Comentado, Tomo III, Imprenta de D. Timoteo Arnaiz, Burgos, 1874.

IZQUIERDO CARRASCO, M.: «La noción y los servicios de seguridad privada», RCSP, núm. 16, 2006.

Izu Belloso, M.J.: «Los conceptos de orden público y seguridad ciudadana tras la Constitución de 1978», Revista Española de Derecho Administrativo, núm. 58, abril-junio 1988.

Javato Martín, A.M.: «El concepto de funcionario público a efectos penales», Revista jurídica de Castilla y León, núm. 23, enero 2011.

LAmarca Pérez, C. (coord.): Delitos. La parte especial del Derecho penal, Ed. Colex, Madrid, 2015. 
LORENTE Velasco, S.M.: Delitos de atentado contra la autoridad, sus agentes y los funcionarios públicos y de resistencia y desobediencia, Ed. Dykinson, Madrid, 2010.

Luzón PeÑa, D.M. (dir.): Enciclopedia penal básica, Ed. Comares, Granada, 2002.

Martín-Retortillo Baquer, L.: «Derechos fundamentales y vía pública», Revista andaluza de Administración Pública, núm. 91, 2015.

—: La cláusula de orden público como límite -impreciso y creciente-del ejercicio de los derechos, Ed. Civitas, Madrid, 1975.

Martín-Retortillo Baquer, L. /De Otto y Pardo, I.: Derecho fundamentales y Constitución, Ed. Civitas, Madrid, 1988.

Morillas Cueva, L. (dir.): Sistema de derecho penal: parte especial, 2. ${ }^{\text {a }}$ ed., Ed. Dykinson, Madrid, 2016.

Muñoz Conde, F.: Derecho Penal. Parte Especial, Ed. Tirant lo Blanch, Valencia, 2017.

Octavio de Toledo y Ubieto, E.: «El bien jurídico protegido en los Capítulos VI y VII del Título II del Código Penal», CPC, núm. 1, 1977.

Parejo Alfonso, L.: Seguridad pública y policía administrativa de seguridad, Ed. Tirant lo Blanch, Valencia, 2008.

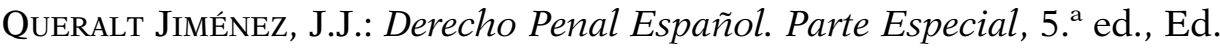
Atelier, Barcelona, 2008.

—: «El concepto penal de funcionario público», CPC, núm. 27, 1985.

Quintero Olivares, G. (dir.): Comentarios a la parte especial del Derecho Penal, 10. ${ }^{\mathrm{a}}$ ed., Ed. Thomson Reuters, Cizur Menor, 2016.

- (dir.): Comentarios al Código Penal Español, Tomo II, Ed. Thomson Reuters, Cizur Menor, 2016.

- (dir.): Comentario a la reforma penal de 2015, Ed. Thomson Reuters, Cizur Menor, 2015.

- (dir.): Comentarios a la Parte Especial del Derecho Penal, 3. a ed., Ed. Aranzadi, Cizur Menor, 2005.

- (dir.): Comentarios al Nuevo Código Penal, 3. ${ }^{\mathrm{a}}$ ed., Ed. Aranzadi, Cizur Menor, 2004.

RAMÓN RiBAS, E.R.: «La derogación jurisprudencial del artículo 24.2 CP (concepto de funcionario público)», Estudios penales y criminológicos, núm. 34, 2014.

Ridaura Martínez, M.J.: Seguridad privada y Derecho fundamentales, Ed. Tirant lo Blanch, Valencia, 2015.

Rodríguez Devesa, J.M.: Derecho Penal Español. Parte Especial, 14. a ed., Ed. Dykinson, Madrid, 1991.

Serrano Gómez, A. y otros: Curso de Derecho Penal. Parte Especial, 3. a ed., Ed. Dykinson, Madrid, 2016. 
Silva Sánchez, J.M. (dir.): Lecciones de Derecho Penal. Parte Especial, Ed. Atelier, Barcelona, 2011.

SuÁrez-Mira Rodríguez, C. (coord.): Manual de Derecho Penal. Tomo II. Parte especial, Ed. Thomson Reuters, Cizur Menor, 2011.

TERRAdillos BAsoco, J.M. (coord.): Lecciones y materiales para el estudio del Derecho penal, tomo III, Derecho penal, Parte Especial, vol. II.

Torres Fernández, M.E.: «Los delitos de atentado en el Código Penal de 1995», Revista Electrónica de Ciencia Penal y Criminología, 1.8 de 1999.

VALEIJe Álvarez, I.: «Reflexiones sobre los conceptos penales de funcionario público, función pública y personas que desempeñan una función pública», $C P C$, núm. 62, 1997.

Vives Antón, T.S. (coord.): Derecho Penal. Parte Especial, Ed. Tirant lo Blanch, Valencia, 2010.

- (coord.): Comentarios al Código Penal de 1995, Vol. II, Ed. Tirant lo Blanch, Valencia, 1996.

ZÁrate Conde, A. (coord.): Derecho Penal. Parte Especial, Ed. Universitaria Ramón Areces, Madrid, 2016. 